\title{
The Regionalisation of Government: A Comparison of Regional Groups of States
}

\author{
Prof. Dr. Jan-Erik Lane* \\ University of Geneva
}

\begin{abstract}
Globalisation poses certain challenges to the states of the world calling for coordination of policies in several areas. International organisations offer one type of arena for global policy-making. However, regionalisation of government has also been a strong trend recently, resulting in the emergence of a few regional groups of states which have become major players in the globalisation game: EU, NAFTA, ASEAN, MERCOSUR, etc. The regionalisation of the nation-state may actually help global governance in international organisations by bringing down the number of players in the unfolding coordination games that globalisation throws up. Understanding the new regional groups of states may be promoted through an analysis of their compactness in terms of key background characteristics such as level of economic, social and political development.
\end{abstract}

$\begin{array}{ll}\text { Keywords: } & \begin{array}{l}\text { Regionalisation, Global Governance, Economic, Social and Political } \\ \text { Development }\end{array} \\ \text { JEL-Codes: } & \text { F02, F14, F15 }\end{array}$

\section{Introduction}

Globalisation has stimulated a debate about governance. Since there is no single world government, the concept of governance has been launched to designate a different form of public intervention in various affairs. Typical for globalisation is the creation of regional mechanisms for economic cooperation or coordination in political affairs. The legal status of these new creations is not quite clear as they may be seen either as merely another kind of international organisations, or they can be regarded as unions or new types of federations of states. We suggest that they should be seen as regional groups of states, i.e. as public mechanisms in terms of which governments may cooperate. Thus, we see them as regional coordination mechanisms, i.e. as an organisational tool to be employed to come to grips with the ever-increasing dependencies that globalisation throws up. To international relations scholars they are intergovernmental institutions or supranational bodies, whereas to comparative politics scholars they constitute unions, i.e. confederations, if not federations of states.

Acknowledgement: 1 am - as always - much indebted to Svantr: Ersson at the University of Umea for doing the ANOVA for this article. 
Regionalisation entails two things. First, whole areas pursue various forms of integration reducing national variations in rules and outcomes by forming blocks of countries. Instead of some 100 states there could be 10 regional organisations, as with the European Union representing now 25 member states. Second, the number of players within international bodies is effectively brought down, as interaction between groups of states may be more transaction cost effective than decision-making with more than 100 players.

With regard to the process of regionalisation of government, one would wish to know which the main regional groups are, why they were formed and how much integration they have accomplished. In this article we will look at the differences between these regional groups as well as the differences within the groups themselves. If the globe is being divided into a few major regional blocks of states, then how do they differ and what is their internal compactness?

Let us first pin down which regional groups of states can be designated as regional coordination mechanisms. Then we will discuss whether these new public institutions have a special logic of evolution starting with economics and ending with politics, as suggested already in the 1960s by economist BELA BALASSA. Finally, we will analyse the compactness question with the help of an analysis of variance of background features of these states.

\section{Regional Groups of States}

When governments accept to create regional mechanisms, then the cement behind cooperation may be geographical position, historical legacy or culture besides economic interdependency. The size of a regional group is often not foreclosed, as new potential entrants arrive and claim membership. The "natural size" of the EU or the ASEAN is impossible to identify. And the recent ambition to create an all South American group, viz the SAFTA or the plan of bringing together South America's two trading blocs, MERCOSUR and the ANDEAN Group, testify to the dynamic nature of regionalization. It is obvious that geographical proximity plays a major role as a foundation for regional coordination, as proximity in space is often connected with economic or political interdependency. However, culture also matters, as with the Arab League and the Moslem Conference. Table 1 shows the major regional coordination mechanisms around 2000. 
Table 1 Key Regional Groups 2000

\begin{tabular}{|l|c|c|l|c|c|}
\hline & $\begin{array}{c}\text { Number } \\
\text { of } \\
\text { members }\end{array}$ & $\begin{array}{c}\text { Estab- } \\
\text { Iished }\end{array}$ & $\begin{array}{c}\text { Type of } \\
\text { organisation: } \\
\text { Main goals }\end{array}$ & $\begin{array}{c}\text { Estimated } \\
\text { population } \\
\text { 2000 } \\
\text { (millions) }\end{array}$ & $\begin{array}{c}\text { Estimated } \\
\text { GDP } \\
\text { around } \\
\text { 1998 } \\
\text { (Billions } \\
\text { US \$) }\end{array}$ \\
\hline $\begin{array}{l}\text { Andean } \\
\text { Community }\end{array}$ & 5 & 1969 & $\begin{array}{l}\text { Promote economic } \\
\text { integration }\end{array}$ & 113 & 560 \\
\hline Arab League & 22 & 1945 & $\begin{array}{l}\text { Promote } \\
\text { cooperation }\end{array}$ & 278 & 989 \\
\hline $\begin{array}{l}\text { Asia-Pacific Economic } \\
\text { Cooperation (APEC) }\end{array}$ & 20 & 1989 & Promote trade & 2559 & 20834 \\
\hline $\begin{array}{l}\text { Association of Southeast } \\
\text { Asian Nations (ASEAN) }\end{array}$ & 10 & 1967 & $\begin{array}{l}\text { Encourage regional } \\
\text { and political } \\
\text { cooperation }\end{array}$ & 521 & 1609 \\
\hline $\begin{array}{l}\text { Central American } \\
\text { Common Market (CACM) }\end{array}$ & 5 & 1960 & $\begin{array}{l}\text { Promote economic } \\
\text { integration }\end{array}$ & 33 & 116 \\
\hline $\begin{array}{l}\text { Commonwealth of } \\
\text { Independent States (CIS) }\end{array}$ & 12 & 1991 & $\begin{array}{l}\text { Coordination betw. } \\
\text { member states }\end{array}$ & 283 & 1354 \\
\hline $\begin{array}{l}\text { Economic Community of } \\
\text { West African States } \\
\text { (ECOWAS) }\end{array}$ & 15 & 1975 & $\begin{array}{l}\text { Promote regional } \\
\text { economic } \\
\text { cooperation }\end{array}$ & 218 & 216 \\
\hline European Union (EU) & 15 & 1957 & $\begin{array}{l}\text { Promote economic } \\
\text { and political } \\
\text { integration }\end{array}$ & 376 & 7695 \\
\hline $\begin{array}{l}\text { Mercado Comun del } \\
\text { Cono Sur (MERCOSUR) }\end{array}$ & 4 & 1991 & $\begin{array}{l}\text { Promote economic } \\
\text { cooperation }\end{array}$ & 216 & 1625 \\
\hline Nordic Council & 5 & 1952 & $\begin{array}{l}\text { Regional } \\
\text { cooperation }\end{array}$ & 24 & 545 \\
\hline $\begin{array}{l}\text { North American Free } \\
\text { Trade Agreement (NAFTA) }\end{array}$ & 3 & 1969 & $\begin{array}{l}\text { Promote free trade } \\
\text { solidarity }\end{array}$ & 412 & 9872 \\
\hline $\begin{array}{l}\text { Organization of the } \\
\text { Islamic Conference (OIC) }\end{array}$ & 56 \\
\hline $\begin{array}{l}\text { Southern African Develop- } \\
\text { ment Community (SADC) }\end{array}$ & 14 & 1992 & $\begin{array}{l}\text { Promote regional } \\
\text { cooperation }\end{array}$ & 201 & 543 \\
\hline
\end{tabular}

Source: By the author

Note: Countries included in these international organisations are listed in Appendix A; membership in these organisations has been identified from CIA (2001). We have not included organisations that focus mainly upon human rights, i.e. the Council of Europe or the Organisation of American States. The Organisation of Africa Unity (now African Union) has been left out, because it accomplished little during its time of existence (1963-2002). 
More than half of the states of the world are members of one or another regional group, although some of these regional groups overlap in membership. Future developments may involve that some of these groups are combined into even bigger groups or that new members enter the existing groups. Thus, the EU now includes 25 states and may soon go up to $30 \mathrm{mem}-$ ber states. There is much talk about one regional integration group for the entire South and Central Americas. In relation to the ASEAN one speaks of 10 plus 3 as if China and Japan were already members.

States may of course be grouped in different ways into regional blocks. Such regional blocks may simply be abstract constructions for the purpose of presenting data. Here, however, we require "agency" or "governance". Thus, a regional coordination mechanism is a regional group of states engaged in some form of coordination, i.e. common decision-making or more. One relevant question raised in the literature concerning the Europeanisation of the nation-state is how far regional integration can proceed without abolishing the autonomy of existing member states. However, most regional groups of states are not much integrated. The groups listed above differ immensely in background characteristics, which may lead to the division of the globe into separate areas with more or less affluence and more or less democracy.

Yet, these regional mechanisms do in no case replace the nation-states. Some of these mechanisms offer merely opportunities for discussions. But others do engage in decision-making resulting in the setting up of rules of various kinds offering a form of public organisation above the nation-states. These regional coordination mechanisms tend to concentrate upon politics - peace and economics - trade. They may be considered as examples of what German institutional economists called Ordnungspolitik, meaning that government defines and enforces a comprehensive set of rules for mainly economic activity. When such institutions are needed for handling the interdependencies between a set of countries, then a regional coordination mechanism may be a transactions cost saving device.

Regional coordination offers a mechanism for states to handle reciprocities. International organisation is of course another mechanism that may offer governance of globalisation. One may pose the question of whether regionalisation or multilateralism is most effective in handling state interdependencies as well as externalities of an economic or environmental nature. Probably, the evolution of events in the $21^{\text {st }}$ century will involve both regionalisation and more of international organisation. Bringing down the num- 
ber of players in the form of regional groups would always be helpful to international state coordination after all.

\section{Logic of Regional Integration}

Looking into the future one may predict that regionalisation will grow. Regional coordination may offer a convenient set of long-run instruments to handle interdependencies and counteract self-seeking strategies that are collectively defeating. Regional coordination has a strong economic foundation and it will grow both through enlargement and through deepening - this is our prediction for the $21^{\text {st }}$ century, although not in the same way for all these regional groups above. Understanding the process of regionalisation requires not only that we observe how the various regional blocks move from weak towards stronger integration. We also need to understand whether there is one basic logic, namely that of economics, behind regionalisation, such as the evolution from a free trade over a Single Market to a complete political union in the form of a federation.

Governments are more and more driven by economic interdependencies to cooperate. One basic rationale of regional coordination is economical, meaning a search for solutions that benefit all participants and the rejection of narrow self-interest strategies. The key question then becomes how far regional economic coordination should go, as one may, following BALASSA (1982) separate between five modes of country integration: (1) Free trade area; (2) Customs union; (3) Internal market: (4) Monetary union; and (5) Political federation. Is there some kind of economic necessity built into regional integration according to the Balassa model? Can regional integration also be driven by politics needs or environmental considerations?

Economic incentives play beyond doubt an important role in processes of regional integration. A number of key theories in economics support the argument about large-scale benefits from increasing efficiency derived from regional integration: increasing trade, more foreign direct investments and economies of scale from production in many countries. Yet, regional integration may also be driven by other forces, such as the environment, the stability of peace and cultural heritage.

A recent interesting example of regional cooperation is the setting up of the Islamic Conference. Some Moslem scholars hint that it may become the official vehicle of the theory of Islamic finance. It would promote the crea- 
tion of institutions that adhere to the principles of Moslem economics and stimulate the integration of the economies of countries adhering somehow to Moslem Law, including of course the Sharia. So far, Moslem cooperation has not resulted in any substantial agreement among member states, which has of course always been true of Arab political or economic cooperation. Political considerations concerning peace and stability loom large for the member states in the ASEAN. The ECOWAS has embarked upon an ambitious plan of regional economic integrations, but it has stalled due to the rising political instability in Western Africa. The military cooperation among several West African states has not succeeded in reducing the dismal consequences of ethnic clashes in several member states of the ECOWAS.

Regionalisation of states may cause that the entire globe will be covered by weak regional coordination mechanisms. Or there may be, forthcoming on a regional level, a few future strong unions of governments which take on more and more of state characteristics. Thus far, the EU is the only regional coordination mechanism that displays stateness, which may be due to the high compactness of the Western European block. Let us make an overview of the major similarities and differences between the regional blocks in the world. The analysis below targets their background characteristics and bypasses entirely the question of how far they have proceeded in regional economic coordination such as intra group trade and investments (Clement 2000, Molle 2001).

\section{Compactness: The between and within group variation}

Let us first ask how similar and different these groups tend to be on overall economic, social and political characteristics such as Gross Domestic Product (GDP), Human Development Index (HDI) and democracy. It would be a major scientific achievement if one could develop a comprehensive index of regional economic integration that would state how far these groups have come in integration, covering trade, investments and ownership. However, here the focus is only upon background characteristics. We will employ the analysis of variance in order to state both the between group differences and the within group differences. The enquiry into regional blocks of states employs standard indicators on economic, social and political development, mixing indicators on level differences with rate of change differences. An institutional set of indices has been added to the performance measures, covering a few aspects of the institutional development of the 
state (perceived corruption) as well as the enforcement of market rules (degree of economic freedom).

The analysis of variance (ANOVA) allows one to summarize in one statistical parameter considerable information about similarities and differences. The key measure is the Eta squared score, which is based upon the relationship between the between groups variation and the total variation: Eta squared $=$ between sums of squares/total sums of squares. The Eta squared scores inform about the compactness of a group (between group variation) reporting upon the differences between the mean values of the different groups as well as the amount of variation within each category (within group variation). Another way of expressing the same thing is to say that the analysis of variance allows one to analyse a set of variables in order to find out whether the method of grouping the cases (countries) matters. Here, we want to know whether regional groups display distinct outcome characteristics on general social attributes, as it is the hypothesis about regional compactness that is the centre of attention here. Perhaps it is the case that regional coordination takes place among similar countries and thus that regional coordination delivers a few major but different blocks of countries?

The similarities and differences in background features are interesting not only from a cross-sectional perspective. They may also be analysed with a longitudinal perspective. Regional coordination would in theory enhance similarities between countries and reduce differences. Thus, economic integration should enhance convergence, not only in economic aspects but also in social and political aspects. This is theory. What, then, are the major findings in an empirical analysis of most recently available information?

Regionalisation of countries is a process, which must be related to the key concepts in development theory, including the North-South division. Does regionalisation reinforce the major differences between the First World and the Third World? Or does regionalisation offer a road towards reducing the North-South divide? Evaluating regional compactness in terms of economic, social and political outcomes, we search for eta squared scores that are higher than (0.5, which would indicate compactness for these regional groups.

Table 2 offers a summery of the findings of several analyses of variation. We find on the one hand sharp regional differences in the major long lasting outcomes of social systems such as affluence, human development and democracy. Moreover, these regional groups differ in terms of the level of corruption in their political systems and the extent of economic freedom in 
their economies. This finding indicates that the world may be dividing itself up in different blocks of similar member states.

Table 2 Long-run features: regional heterogeneity (Means and Eta squares)

\begin{tabular}{|l|c|c|c|c|}
\hline Variable & Mean & Eta sq. & Sig. & N \\
GDPCPP75 & 2655 &, 311 &, 000 & 112 \\
GDPCPP90 & 6120 &, 621 &, 000 & 145 \\
GDPCPP95 & 7109 &, 648 &, 000 & 151 \\
CORR98 & 5,02 &, 561 &, 000 & 94 \\
CORR00 & 5,23 &, 584 &, 000 & 101 \\
CORR02 & 5,37 &, 573 &, 000 & 105 \\
HDI1975 &, 587 &, 768 &, 000 & 104 \\
HDI1985 &, 632 &, 696 &, 000 & 116 \\
HDI1990 &, 651 &, 678 &, 000 & 124 \\
HDI1995 &, 672 &, 683 &, 000 & 125 \\
HDI1999 &, 677 &, 610 &, 000 & 158 \\
ECFR75 & 5,35 &, 385 &, 001 & 92 \\
ECFR90 & 5,72 &, 444 &, 000 & 118 \\
ECFR95 & 6,33 &, 552 &, 000 & 117 \\
HR7276 & 4,71 &, 574 &, 000 & 138 \\
HR8185 & 4,89 &, 645 &, 000 & 145 \\
HR9195 & 5,14 &, 611 &, 000 & 165 \\
HR9501 & 5,23 &, 623 &, 000 & 169 \\
\hline
\end{tabular}

Source: By the author

Note: $\quad$ See Appendix 2-9 for the detailed analysis; Appendix 10 contains information about the variables employed in this table.

The major regional groups of the world converge upon certain background characteristics such as affluence (GDP), the market economy (ECFR), democracy (HR) and corruption (CORR). The within group differences on these indicators is consistently smaller than the between group differences. Thus, the various regional groups of states display compactness in terms of basic features.

On the other hand, there is little regional effect in short-term outcomes such as inflation and economic growth. Interestingly, there is also no regional variation in IMPEX, or the degree of openness of the economies of these countries. Globalisation appears to drive up the IMPEX indicator for almost all countries independently of regional group (Table 3 ). The differences within each block are larger than the between block variation on 
short-term outcomes meaning that groups do not display a consistent pattern on these indicators. Since these short-term indicators tap economic performance, one may conclude that the regional blocks do not develop differently in the short-run.

Table 3 Short-run features: regional heterogeneity (Means and Eta squares)

\begin{tabular}{|l|c|c|c|c|}
\hline Variable & Mean & Eta sq. & Sig. & N \\
GRO6073 & 3,1 &, 149 &, 058 & 127 \\
GRO7385 & 1,3 &, 282 &, 000 & 129 \\
GRO8594 & $-0,1$ &, 434 &, 000 & 149 \\
GRO9098 & 0,3 &, 457 &, 000 & 154 \\
IMPEX7598 & 71,4 &, 078 &, 417 & 160 \\
IMPEX75 & 64,3 &, 084 &, 596 & 124 \\
IMPEX98 & 77,5 &, 223 &, 008 & 115 \\
INFL6173 & 12,8 &, 083 &, 931 & 74 \\
INFL7390 & 56,4 &, 223 &, 031 & 98 \\
INFL9098 & 40,7 &, 215 &, 021 & 107 \\
\hline
\end{tabular}

Source: By the author

Note: $\quad$ See Appendix 2-9 for the detailed analysis; Appendix 10 contains information about the variables employed in this table.

We will now proceed to document the main differences between the regional groups of the globe. Let us compare the overall information about mean values in Table 2 and Table 3 with the detailed information about the separate regional groups in Appendix 2-9. As things now stand, the regional groups of the world display strong variation on the following properties:

\subsection{Affluence (GDP)}

The average GDP per capita of all the countries in the various regional groups is roughly 8000 international US\$. However, the GDP means of the regional groups vary strongly: NAFTA $=20297, \mathrm{EU}=21226$, Arab League $=8001$, MERCOSUR $=7887$, ASEAN $=6086$, ANDEAN $=4273, \mathrm{CACM}$ $=3620, \mathrm{CIS}=3209, \mathrm{SADE}=3126$ and ECOWAS $=1109$. When the EU has swallowed the Visegrad group in 2004, then the lead of the NAFTA group will become pronounced. It is perhaps surprising that the Arab League is doing so well (the petrol states or rentier states), but there should be concern about how poorly the CIS group performs. That the ECOWAS group is at the lower end of the GDP scale comes as no surprise though. 
The purpose behind regional coordination is of course to raise country affluence through trade and foreign direct investment. The regional coordination mechanisms do not vary systematically on economic growth, as the yearly changes in economic output depend upon many factors, including the international business cycle. However, for the period 1990-2000 we note that the Eta squared statistic reaches above 0.5. Interestingly, it is not the process of the rich becoming richer and the poor getting poorer that are reflected in these data. Strong economic performance is displayed by the following groups during this period: ASEAN, MERCOSUR, CACM and ANDEAN. Regionalisation may enhance both economic growth in and convergence among member countries by maximising intra group trade as well as inter group trade with other regions. This may lift one entire region, but the immense debacle in Zimbabwe hardly helpd the SADC.

We may conclude that the globe harbours regional groups along a clear separation between superrich, medium affluent and poor countries. It remains to be seen whether trade and investment can change this rich - poor split, as it should according to established economic theory. It is the task of the WTO to reform the rules of the international economy so that it presents a fair opportunity to the poor groups to reduce the gap, if not catch up.

\subsection{Human development}

The human development index taps the quality of life, which is not the same as affluence. Since social development is related to economic development one may expect to find that the Eta squared statistic is above 0.5 for the human development index. As a matter of fact, we find here the highest Eta squared score meaning that almost all of the variation among countries refers to between groups variation. Some of the regional groups of the world offer much better quality of life than others. The human development index ranges from 0 to 1 . Close to 1 we have the NAFTA (0.887) and the EU (0.917), which latter group scores somewhat higher than the former despite the GDP advantage of the NAFTA. Very low group scores on HDI are to be found with the ECOWAS (0.398) and the SADC (0.515). The ASEAN group does not score high (0.676) despite its immense growth record. Surprising low is also the HDI for the Arab League (0.670), which hardly will climb in the early years of the $21^{\text {st }}$ century due to the Iraq war. One can understand the ambition of many people living in the Third World to emigrate to either NAFTA or EU countries. 


\subsection{Democracy}

The normative status of affluence and human development is hardly contested among the cultures of the world. Matters are different with regard to democracy, which is here measured with the enforcement of human rights. The high Eta squared score indicates that the regional groups endorse different values in relation to democracy, reflecting the relevance of cultural legacies. The democracy scores ranges from 1 to 10 . The spread is huge, from the EU (9.61) and the NAFTA (8.86) to ASEAN (3.80), the Arab League (2.56), ECOWAS (4.92) and CIS (3.96). In relation to the extremely low scores for the Arab League one may suspect that religion matters, but it is an unresolved question though whether Buddhism in particular or ASEAN values in general is one cause behind the low scores for the ASEAN. The low scores for ECOWAS and CIS reflect the anarchy in these regions more than explicit adherence to authoritarianism. MERCOSUR (7.54) and ANDEAN (6.68) do not perform as badly in the late 1990s as they used to do after the Second World War.

However, when it comes to the following aspects, then the regional groups are not that different.

\subsection{Openness and Inflation}

Regional groups of trading partners are created in order to enhance imports and export stimulating economic growth in a variable sum game where all members in the group win. This is not only the officially stated goal of these regional coordination mechanisms but also the implication of all the economic theories of trade and investments, from RICARDO over HECKSCHER and OHLIN to KRUGMAN (KRUGMAN and OBSTFELD, 2002). Increases in trade may be measured by the openness index, which is based upon the following equation: Impex $=($ Imports + Exports $) /$ GDP, which gives a percentage number that indicates the extent of openness. It can actually surpass one hundred per cent as with the entrepot countries. We find that openness has increased since 1975. As a matter of fact, the increase is quite substantial, from 65 per cent to 78 per cent as the average for all countries. This is a high score that reflects globalisation in general. How about the variation between the regional groups?

The regional groups making up the so-called Triad have very high openness scores: the ASEAN, the EU and NAFTA. While the ASEAN scores above 
100 per cent, the other two groups surpass 50 per cent. There is a quite dramatic rise in openness for NAFTA during the 1990s. The openness scores for the Arab League and the CACM are also quite high, whereas the remaining groups do not surpass 50 per cent in openness.

One may certainly argue that the more there is of trade the more affluent is the country, all other things equal. A high degree of openness distinguishes the rich countries. But other factors also play a role in determining the wealth of nations, such as e.g. inflation. It is a cardinal truth in monetarism that high levels of inflation are negative for economic growth. How do the regional groups compare on the rates of inflation?

An interesting finding is that inflation is quite high on an average for all countries. There is immense variation between the countries, but not between the groups, the Eta squared statistic being close to 0. Only the EU has stable low inflation rates as a group. The standard deviations within each of the other groups are quite high meaning that there are a few countries in each block or group that are characterized by high rates of inflation, or hyperinflation.

\section{Security First, Prosperity Later}

The simple mechanism within the Balassa model is based on an economic rationale, almost amounting to economic determinism according to the idea that more and more of trade and investments between the economies of two countries must lead to institution building. Moving from a free trade area to an internal market over a customs union and ending up in a monetary union may appear as the simple and straightforward application of economic efficiency maximizing output or transaction costs saving. But is economic rationale the only relevant consideration?

However, there is no quick road to regional economic integration. To put things bluntly, the ECOWAS in Western Africa aiming at the integration of 15 countries attempted to apply the Balassa model in a very short period of time, tearing down borders and handing out common passports. The outcome has been the disruption of an entire country - Cote d'Ivoire, where the population in the South claims that many in the North are foreigners, coming from Burkina Faso. More is involved in regional institution building than only economic forces. 
Looking more closely at the regional groups of the world, one sees the relevance of political considerations such as national security, the guarantee of peace and culture. The economic institutions of the Balassa model - free trade, the Common External Tariff (CET), free movement and common money - could not even get moving without state security being guaranteed somehow. State neighbours may feel that the security provided through the UN framework is not enough. Regionalisation may make the security anxiety of neighbours explicit, providing reciprocal guarantees for borders and peace before economic integration starts. By joining a regional group, the partners communicate that they wish to collaborate, which may reduce mutual suspicion. Achieving such a minimal guarantee for borders may constitute a goal in itself as well as a means to economic integration.

Thus, national security may be an independent objective in regional integration processes. It may seem contradictory for a country that aims at establishing or protecting its national identity and security to join a regional group of states. But regionalisation may be a most effective means to state respect and state consolidation. A regional group offers a mechanism for discussing about the issues that cause concern and it may also hand down means of reconciliation or arbitration. Allocating peace and stability may be a time consuming task, but its benefits cannot be doubted. Thus, politics affects the process of regional integration to a much greater extent than the Balassa model implies. Besides politics there is also culture.

Regionalisation may offer a more efficient tool for enhancing state stability and cultural respect than relying upon the guarantees that the existing international order offers. Where there is deep suspicion and mistrust, merely arguing to meet yearly may mean much. By joining in a regional group, a government accepts the rules of the game and sends a message of a conditional peaceful attitude. Regional coordination mechanisms may include conflict prevention devices as well as offer arbitration possibilities. Yet, the key to success is the institutionalisation of meetings between heads of states and governments as well as between ministers and bureaucrats. This is the basic logic of the ASEAN, I suggest.

There is no doubt that economic incentives play a major role in shaping events in the evolution of societies. Perhaps economic incentives also promote the arrival at efficient and transaction cost saving institutions at the macro level of human organisation, as "Law and Economics" teaches. However, economic motivation, whether in the form of the simple and brutal instinct for gain, or the VEBLEN (1994) sophisticated kind of economic 
arrogance or the religiously inspired Weberian capitalist ethic, does not cover more than 50 per cent of human behaviour. Culture is a major aspect of human interaction, dividing societies into communities along ethnic or religious cleavages. This has huge relevance for the step from a customs union to an internal market, a qualitative leap that BALASSA does not capture. To integrate the labour markets of countries with entirely different ethnic or religious compositions - that must be a challenge, or even a recipe for political tensions (Tovias 1991).

\section{Globalisation and Regionalisation}

There may be something of policy diffusion going on with regard to regionalisation. Since the Europeans have done it in such a coherent manner and the Americans also engage in it, not without success, then the regional model must suit each and every state around the globe. Yet, the tensions within the Arab League, the ECOWAS and the CIS give cause for critical reflection about the ends and means of regionalisation.

Regionalisation may also be interpreted from the above perspective of increased global governance. A regional group of states may be stronger than each single government acting alone in the major arenas of global governance. When a regional block emerges in the international organisations, then this creates an incentive for the remaining governments to look into the possibilities of joint action as a response. Given one global economy linking up almost all countries in the world with open economies, the bargaining over the basic rules of trade and investments in the real and financial economy is a game with very high stakes for all players. Thus, increasing their bargaining strength in the global governance of the world economy, the governments of states link up with each other in a few regional groups of states. In so doing, they also without intention make it easier to arrive at global solutions, since the number of players in any agreement is sharply reduced as a consequence.

Most of the regional coordination mechanisms studied above are free trade area organisations. MERCOSUR has taken the step towards a common customs union, but only the EU has a functioning internal market and in addition a single currency. The cohesiveness of the EU relies not only upon public law as the basic mechanism of integration but represents also the high political compactness of the group as displayed in an analysis of variance. 


\section{Conclusion}

We have reported upon a tentative analysis of variance of the major regional groups of the world. These cover now more than half of the existing states of the globe. The major finding is that these regional coordination mechanisms display considerable differences in background characteristics such as affluence, social development and democracy. Can we conclude that the globe will be reduced to the competition and cooperation between three to four major regional blocks of states within a period of 50 years, the EU, NAFTA, MERCOSUR and ASEAN? Regional integration in the Arab and Moslem world appears to be slower, which is also true for the Pacific Rim despite several efforts such as the immense APEC and the smaller Pacific Islands Forum.

It would be premature to predict growing regional differences because there are much intra group differences on several of the aspects studied here, such as openness, inflation and economic growth. But there is a risk that three regional groups - the EU, NAFTA and ASEAN - will develop in a similar manner while the other regional groups of states become more different from these three rich blocks as well as marginalised during the same process of regionalisation. However, human rights and the rule of law remain weakly institutionalised in the ASEAN.

Looking into the various regional groups of states, one discovers that economics does not offer the sole motivation for regionalisation. National security and state stability loom large for instance with the ASEAN and the ECOWAS. There is no evidence about a Balassa effect meaning that once regionalisation starts, then it has an internal necessity propelling it towards ever-deeper integration. Perhaps the prudent and cautious NAFTA model is more viable than the risky EU model, in the long run? A regional group of states may also be so weak that it is more of a "Potemkin Village" like for instance the CIS, where the tensions between the member states are simply too large to allow common agency. Finally, it may be added that more research is needed upon how these regional coordination mechanisms really work. Only with regard to the EU are there in depth analyses of how the formal organisation operates in reality. The analysis above has not been able to penetrate behind the scene, which would require access to entirely different data than what is available at the present.

All forms of regional organisation stem from agreements between states. A state may be member of more than one regional group, as agreements dis- 
play, so-called variable geometry. Thus, Venezuela for instance is now an associate member of ANDEAN (free trade group) and full member of MERCOSUR (customs union group), firmly resisting the extension of NAFTA over all Americas - the FTAA. The motivation behind regional treaties varies, as when e.g. the UAE is a member of the compact Gulf Cooperation Council (GCC), the loose Arab League and the amorphous Islamic Conference. The carpet of regional agreements is rapidly becoming so patchy that regional organisation must start running up heavy transaction costs. States (like e.g. China) may still employ bilateral agreements in order to coordinate economically. Just as too many bilateral treaties may threaten a regional group, so too compact regional groups may restrict global coordination through the WTO framework. 


\section{Appendices}

Appendix 1 Countries and regional organidations

\begin{tabular}{|c|c|c|c|}
\hline Country & Regional Group & Country & Regional Group \\
\hline $\begin{array}{l}\text { Bolivia } \\
\text { Colombia } \\
\text { Ecuador } \\
\text { Peru } \\
\text { Venezuela, RB } \\
\text { Australia } \\
\text { Canada } \\
\text { Chile } \\
\text { China } \\
\text { Hong Kong, China } \\
\text { Indonesia } \\
\text { Japan } \\
\text { Korea, Rep. } \\
\text { Malaysia } \\
\text { Mexico } \\
\text { New Zealand } \\
\text { Papua New Guinea } \\
\text { Peru } \\
\text { Philippines } \\
\text { Russian Federation } \\
\text { Singapore } \\
\text { Taiwan } \\
\text { Thailand } \\
\text { United States } \\
\text { Vietnam } \\
\text { Algeria } \\
\text { Egypt, Arab Rep. } \\
\text { Iraq } \\
\text { Jordan } \\
\text { Kuwait } \\
\text { Lebanon } \\
\text { Libya } \\
\text { Mauritania } \\
\text { Morocco } \\
\text { Oman } \\
\text { Saudi Arabia } \\
\text { Somalia } \\
\text { Sudan } \\
\text { Syrian Arab Republic } \\
\text { Tunisia } \\
\text { United Arab Emirates } \\
\text { Yemen, Rep. } \\
\text { Bahrain } \\
\text { Quatar } \\
\text { Burma-Myanmar } \\
\text { Cambodia } \\
\text { Indonesia } \\
\text { Lao PDR } \\
\text { Malaysia } \\
\text { Philippines } \\
\text { Man }\end{array}$ & $\begin{array}{l}\text { Andean community } \\
\text { Andean community } \\
\text { Andean community } \\
\text { Andean community } \\
\text { Andean community } \\
\text { apec } \\
\text { apec } \\
\text { apec } \\
\text { apec } \\
\text { apec } \\
\text { apec } \\
\text { apec } \\
\text { apec } \\
\text { apec } \\
\text { apec } \\
\text { apec } \\
\text { apec } \\
\text { apec } \\
\text { apec } \\
\text { apec } \\
\text { apec } \\
\text { apec } \\
\text { apec } \\
\text { apec } \\
\text { apec } \\
\text { arab league } \\
\text { arab league } \\
\text { arab league } \\
\text { arab league } \\
\text { arab league } \\
\text { arab league } \\
\text { arab league } \\
\text { arab league } \\
\text { arab league } \\
\text { arab league } \\
\text { arab league } \\
\text { arab league } \\
\text { arab league } \\
\text { arab league } \\
\text { arab league } \\
\text { arab league } \\
\text { arab league } \\
\text { arab league } \\
\text { arab league } \\
\text { asean } \\
\text { asean } \\
\text { asean } \\
\text { asean } \\
\text { asean } \\
\text { asean }\end{array}$ & 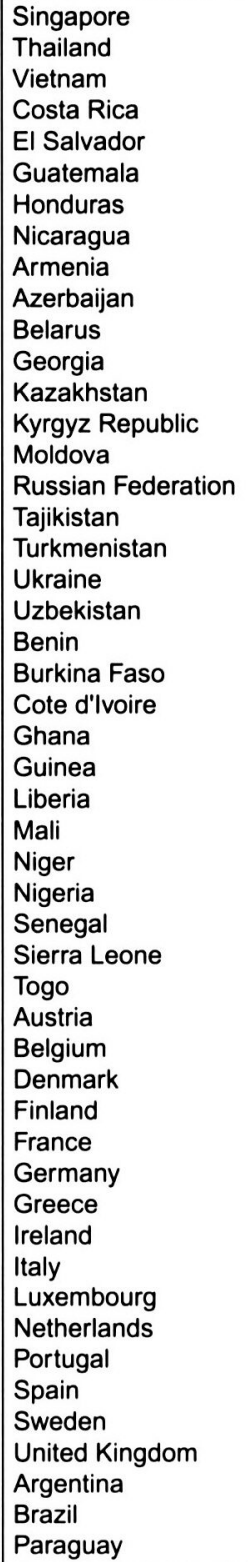 & $\begin{array}{l}\text { asean } \\
\text { asean } \\
\text { asean } \\
\text { cacm } \\
\text { cacm } \\
\text { cacm } \\
\text { cacm } \\
\text { cacm } \\
\text { cis } \\
\text { cis } \\
\text { cis } \\
\text { cis } \\
\text { cis } \\
\text { cis } \\
\text { cis } \\
\text { cis } \\
\text { cis } \\
\text { cis } \\
\text { cis } \\
\text { cis } \\
\text { ecowas } \\
\text { ecowas } \\
\text { ecowas } \\
\text { ecowas } \\
\text { ecowas } \\
\text { ecowas } \\
\text { ecowas } \\
\text { ecowas } \\
\text { ecowas } \\
\text { ecowas } \\
\text { ecowas } \\
\text { ecowas } \\
\text { eu } \\
\text { eu } \\
\text { eu } \\
\text { eu } \\
\text { eu } \\
\text { eu } \\
\text { eu } \\
\text { eu } \\
\text { eu } \\
\text { eu } \\
\text { eu } \\
\text { eu } \\
\text { eu } \\
\text { eu } \\
\text { eu } \\
\text { mercosur } \\
\text { mercosur } \\
\text { mercosur }\end{array}$ \\
\hline
\end{tabular}




\begin{tabular}{|c|c|c|c|}
\hline Country & Regional Group & Country & Regional Group \\
\hline $\begin{array}{l}\text { Uruguay } \\
\text { Canada } \\
\text { Mexico } \\
\text { United States } \\
\text { Denmark } \\
\text { Finland } \\
\text { Iceland } \\
\text { Norway } \\
\text { Sweden } \\
\text { Afghanistan } \\
\text { Albania } \\
\text { Bangladesh } \\
\text { Cameroon } \\
\text { Chad } \\
\text { Gabon } \\
\text { Iran, Islamic Rep. } \\
\text { Pakistan } \\
\text { Turkey } \\
\text { Uganda } \\
\text { Algeria } \\
\text { Azerbaijan } \\
\text { Bahrain } \\
\text { Benin } \\
\text { Burkina Faso } \\
\text { Cote d'Ivoire } \\
\text { Egypt, Arab Rep. } \\
\text { Guinea } \\
\text { Indonesia } \\
\text { Iraq } \\
\text { Jordan } \\
\text { Kazakhstan } \\
\text { Kuwait } \\
\text { Kyrgyz Republic } \\
\text { Lebanon } \\
\text { Libya }\end{array}$ & $\begin{array}{l}\text { mercosur } \\
\text { nafta } \\
\text { nafta } \\
\text { nafta } \\
\text { nordic } \\
\text { nordic } \\
\text { nordic } \\
\text { nordic } \\
\text { nordic } \\
\text { org islamic conference } \\
\text { org islamic conference } \\
\text { org islamic conference } \\
\text { org islamic conference } \\
\text { org islamic conference } \\
\text { org islamic conference } \\
\text { org islamic conference } \\
\text { org islamic conference } \\
\text { org islamic conference } \\
\text { org islamic conference } \\
\text { org islamic conference } \\
\text { org islamic conference } \\
\text { org islamic conference } \\
\text { org islamic conference } \\
\text { org islamic conference } \\
\text { org islamic conference } \\
\text { org islamic conference } \\
\text { org islamic conference } \\
\text { org islamic conference } \\
\text { org islamic conference } \\
\text { org islamic conference } \\
\text { org islamic conference } \\
\text { org islamic conference } \\
\text { org islamic conference } \\
\text { org islamic conference } \\
\text { org islamic conference }\end{array}$ & $\begin{array}{l}\text { Malaysia } \\
\text { Mali } \\
\text { Mauritania } \\
\text { Morocco } \\
\text { Mozambique } \\
\text { Niger } \\
\text { Nigeria } \\
\text { Oman } \\
\text { Qatar } \\
\text { Saudi Arabia } \\
\text { Senegal } \\
\text { Sierra Leone } \\
\text { Somalia } \\
\text { Sudan } \\
\text { Syrian Arab Republic } \\
\text { Tajikistan } \\
\text { Togo } \\
\text { Tunisia } \\
\text { Turkmenistan } \\
\text { United Arab Emirates } \\
\text { Uzbekistan } \\
\text { Yemen, Rep. } \\
\text { Angola } \\
\text { Botswana } \\
\text { Congo, Kinshasa } \\
\text { Lesotho } \\
\text { Malawi } \\
\text { Mauritius } \\
\text { Mozambique } \\
\text { Namibia } \\
\text { South Africa } \\
\text { Tanzania } \\
\text { Zambia } \\
\text { Zimbabwe }\end{array}$ & $\begin{array}{l}\text { org islamic conference } \\
\text { org islamic conference } \\
\text { org islamic conference } \\
\text { org islamic conference } \\
\text { org islamic conference } \\
\text { org islamic conference } \\
\text { org islamic conference } \\
\text { org islamic conference } \\
\text { org islamic conference } \\
\text { org islamic conference } \\
\text { org islamic conference } \\
\text { org islamic conference } \\
\text { org islamic conference } \\
\text { org islamic conference } \\
\text { org islamic conference } \\
\text { org islamic conference } \\
\text { org islamic conference } \\
\text { org islamic conference } \\
\text { org islamic conference } \\
\text { org islamic conference } \\
\text { org islamic conference } \\
\text { org islamic conference } \\
\text { sadc } \\
\text { sadc } \\
\text { sadc } \\
\text { sadc } \\
\text { sadc } \\
\text { sadc } \\
\text { sadc } \\
\text { sadc } \\
\text { sadc } \\
\text { sadc } \\
\text { sadc } \\
\text { sadc }\end{array}$ \\
\hline
\end{tabular}

Source: By the author.

Note: $\quad$ Countries listed as members of APEC, the Islamic Conference and the Nordic Council may also be mem-bers of other international organisations. 
Appendix 2 GDP/capita in US \$ (PPPs) 1975-1998

\begin{tabular}{|c|c|c|c|c|c|c|c|}
\hline Group & & $\begin{array}{c}\text { CDPCPP } \\
75\end{array}$ & $\begin{array}{c}\text { GDPCPP } \\
80\end{array}$ & $\begin{array}{c}\text { GDPCPP } \\
85\end{array}$ & $\begin{array}{c}\text { GDPCPP } \\
90\end{array}$ & $\begin{array}{c}\text { CDPCPP } \\
95\end{array}$ & $\begin{array}{c}\text { GDPCPP } \\
98\end{array}$ \\
\hline nafta & $\begin{array}{l}\text { Mean } \\
\mathrm{N} \\
\text { Std. Dev. }\end{array}$ & $\begin{array}{r}5796 \\
3 \\
2972\end{array}$ & $\begin{array}{r}9362 \\
3 \\
4498\end{array}$ & $\begin{array}{r}11929 \\
3 \\
6077\end{array}$ & $\begin{array}{r}16144 \\
3 \\
8709\end{array}$ & $\begin{array}{r}19180 \\
3 \\
10714\end{array}$ & $\begin{array}{r}20297 \\
3 \\
11314\end{array}$ \\
\hline mercusor & $\begin{array}{l}\text { Mean } \\
\mathrm{N} \\
\text { Std. Dev. }\end{array}$ & $\begin{array}{r}2545 \\
4 \\
1189\end{array}$ & $\begin{array}{r}4356 \\
4 \\
1567\end{array}$ & $\begin{array}{r}4517 \\
4 \\
1481\end{array}$ & $\begin{array}{r}5643 \\
4 \\
1476\end{array}$ & $\begin{array}{r}7434 \\
4 \\
2571\end{array}$ & $\begin{array}{r}7887 \\
4 \\
3271\end{array}$ \\
\hline asean & $\begin{array}{l}\text { Mean } \\
\mathrm{N} \\
\text { Std. Dev. }\end{array}$ & $\begin{array}{r}1349 \\
5 \\
931 \\
\end{array}$ & $\begin{array}{r}2509 \\
5 \\
1801 \\
\end{array}$ & $\begin{array}{r}3390 \\
5 \\
2759 \\
\end{array}$ & $\begin{array}{r}4280 \\
7 \\
4462 \\
\end{array}$ & $\begin{array}{r}5920 \\
8 \\
7046 \\
\end{array}$ & $\begin{array}{r}6086 \\
8 \\
7679 \\
\end{array}$ \\
\hline eu & $\begin{array}{l}\text { Mean } \\
\mathrm{N} \\
\text { Std. Dev. }\end{array}$ & $\begin{array}{r}5310 \\
14 \\
1179 \\
\end{array}$ & $\begin{array}{r}8525 \\
14 \\
1799 \\
\end{array}$ & $\begin{array}{r}10923 \\
14 \\
2421\end{array}$ & $\begin{array}{r}16081 \\
14 \\
3425 \\
\end{array}$ & $\begin{array}{r}19994 \\
15 \\
4485\end{array}$ & $\begin{array}{r}21226 \\
15 \\
4565\end{array}$ \\
\hline $\begin{array}{l}\text { arab } \\
\text { league }\end{array}$ & $\begin{array}{l}\text { Mean } \\
\mathrm{N} \\
\text { Std. Dev. }\end{array}$ & $\begin{array}{r}3303 \\
9 \\
5282 \\
\end{array}$ & $\begin{array}{r}4761 \\
10 \\
7277 \\
\end{array}$ & $\begin{array}{r}4372 \\
10 \\
5463 \\
\end{array}$ & $\begin{array}{r}4411 \\
12 \\
5468\end{array}$ & $\begin{array}{r}4981 \\
12 \\
5373 \\
\end{array}$ & $\begin{array}{r}8001 \\
16 \\
7574 \\
\end{array}$ \\
\hline sadc & $\begin{array}{l}\text { Mean } \\
\mathrm{N} \\
\text { Std. Dev. }\end{array}$ & $\begin{array}{r}1151 \\
8 \\
1258 \\
\end{array}$ & $\begin{array}{r}1746 \\
10 \\
1707 \\
\end{array}$ & $\begin{array}{r}2016 \\
11 \\
1818 \\
\end{array}$ & $\begin{array}{r}2609 \\
12 \\
2429 \\
\end{array}$ & $\begin{array}{r}3078 \\
12 \\
2933 \\
\end{array}$ & $\begin{array}{r}3126 \\
12 \\
3063 \\
\end{array}$ \\
\hline ecowas & $\begin{array}{l}\text { Mean } \\
\mathrm{N} \\
\text { Std. Dev. }\end{array}$ & $\begin{array}{r}491 \\
10 \\
206 \\
\end{array}$ & $\begin{array}{r}714 \\
10 \\
291 \\
\end{array}$ & $\begin{array}{r}752 \\
10 \\
274 \\
\end{array}$ & $\begin{array}{r}984 \\
11 \\
357 \\
\end{array}$ & $\begin{array}{r}1085 \\
11 \\
418 \\
\end{array}$ & $\begin{array}{r}1109 \\
11 \\
463 \\
\end{array}$ \\
\hline cacm & $\begin{array}{l}\text { Mean } \\
\mathrm{N} \\
\text { Std. Dev. }\end{array}$ & $\begin{array}{r}1530 \\
5 \\
461 \\
\end{array}$ & $\begin{array}{r}2108 \\
5 \\
656\end{array}$ & $\begin{array}{r}2172 \\
5 \\
683\end{array}$ & $\begin{array}{r}2784 \\
5 \\
1145\end{array}$ & $\begin{array}{r}3584 \\
5 \\
1534\end{array}$ & $\begin{array}{r}3620 \\
5 \\
1531\end{array}$ \\
\hline andean & \begin{tabular}{|l} 
Mean \\
$\mathrm{N}$ \\
Std. Dev.
\end{tabular} & $\begin{array}{r}1971 \\
4 \\
741 \\
\end{array}$ & $\begin{array}{r}2924 \\
4 \\
896 \\
\end{array}$ & $\begin{array}{r}3189 \\
4 \\
882 \\
\end{array}$ & $\begin{array}{r}3567 \\
5 \\
1666 \\
\end{array}$ & $\begin{array}{r}4361 \\
5 \\
1731 \\
\end{array}$ & $\begin{array}{r}4273 \\
5 \\
1657 \\
\end{array}$ \\
\hline cis & $\begin{array}{l}\text { Mean } \\
\mathrm{N} \\
\text { Std. Dev. }\end{array}$ & $\begin{array}{r}3270 \\
1\end{array}$ & $\begin{array}{r}6156 \\
1\end{array}$ & $\begin{array}{r}8736 \\
1\end{array}$ & $\begin{array}{r}5752 \\
10 \\
2298\end{array}$ & $\begin{array}{r}3018 \\
12 \\
1738\end{array}$ & $\begin{array}{r}3209 \\
11 \\
1800\end{array}$ \\
\hline apec & $\begin{array}{l}\text { Mean } \\
\mathrm{N} \\
\text { Std. Dev. }\end{array}$ & $\begin{array}{r}2978 \\
17 \\
2511\end{array}$ & $\begin{array}{r}4935 \\
17 \\
3913\end{array}$ & $\begin{array}{r}6506 \\
17 \\
5178\end{array}$ & $\begin{array}{r}9505 \\
18 \\
7071\end{array}$ & $\begin{array}{r}11791 \\
19 \\
8922\end{array}$ & $\begin{array}{r}12043 \\
19 \\
9279\end{array}$ \\
\hline nordic & $\begin{array}{l}\text { Mean } \\
\mathrm{N} \\
\text { Std. Dev. }\end{array}$ & $\begin{array}{r}5991 \\
5 \\
449\end{array}$ & $\begin{array}{r}9932 \\
5 \\
936\end{array}$ & $\begin{array}{r}13161 \\
5 \\
1018\end{array}$ & $\begin{array}{r}18230 \\
5 \\
1145\end{array}$ & $\begin{array}{r}21837 \\
5 \\
2394\end{array}$ & $\begin{array}{r}23435 \\
5 \\
2562\end{array}$ \\
\hline $\begin{array}{l}\text { org } \\
\text { islamic } \\
\text { conf }\end{array}$ & $\begin{array}{l}\text { Mean } \\
\mathrm{N} \\
\text { Std. Dev. }\end{array}$ & $\begin{array}{r}1685 \\
27 \\
3250\end{array}$ & $\begin{array}{r}2395 \\
29 \\
4564\end{array}$ & $\begin{array}{r}2358 \\
30 \\
3524\end{array}$ & $\begin{array}{r}2943 \\
39 \\
3479\end{array}$ & $\begin{array}{r}3026 \\
40 \\
3528\end{array}$ & $\begin{array}{r}4400 \\
43 \\
5559\end{array}$ \\
\hline Total & \begin{tabular}{|l} 
Mean \\
$\mathrm{N}$ \\
Std. Dev. \\
Eta sq. \\
Sig.
\end{tabular} & $\begin{array}{r}2655 \\
112 \\
2931 \\
, 3 \\
.000\end{array}$ & $\begin{array}{r}4111 \\
117 \\
4436 \\
.4 \\
.000\end{array}$ & $\begin{array}{r}4846 \\
119 \\
4926 \\
, 6 \\
, 000\end{array}$ & $\begin{array}{r}6120 \\
145 \\
6355 \\
, 6 \\
, 000\end{array}$ & $\begin{array}{r}7109 \\
151 \\
7893 \\
, 6 \\
, 000\end{array}$ & $\begin{array}{r}7944 \\
157 \\
8501 \\
.6 \\
, 000\end{array}$ \\
\hline
\end{tabular}

Source: By the author. 
Appendix 3 Economic growth 1960-98: year to year

\begin{tabular}{|c|c|c|c|c|c|}
\hline Group & & GR06073 & GR07385 & GR08594 & GR09098 \\
\hline Nafta & $\begin{array}{l}\text { Mean } \\
\mathrm{N} \\
\text { Std. Dev. }\end{array}$ & $\begin{array}{l}3,4 \\
3 \\
, 3 \\
\end{array}$ & $\begin{array}{l}1,3 \\
3 \\
, 2 \\
\end{array}$ & $3^{.8}$ & $\begin{array}{l}1,3 \\
3 \\
, 8 \\
\end{array}$ \\
\hline Mercusor & $\begin{array}{l}\text { Mean } \\
\mathrm{N} \\
\text { Std. Dev. }\end{array}$ & $\begin{array}{r}2000 \\
4 \\
1,6 \\
\end{array}$ & $\begin{array}{l}1,1 \\
4 \\
2,7 \\
\end{array}$ & $\begin{array}{l}1,4 \\
4 \\
1,4 \\
\end{array}$ & $\begin{array}{l}2,4 \\
4 \\
1,9 \\
\end{array}$ \\
\hline Asean & $\begin{array}{l}\text { Mean } \\
N \\
\text { Std. Dev. }\end{array}$ & $\begin{array}{l}2,4 \\
9 \\
2,6 \\
\end{array}$ & $\begin{array}{l}3,9 \\
6 \\
1,7 \\
\end{array}$ & $\begin{array}{l}5,1 \\
6 \\
2,6 \\
\end{array}$ & $\begin{array}{l}4,1 \\
9 \\
1,8 \\
\end{array}$ \\
\hline eu & $\begin{array}{l}\text { Mean } \\
N \\
\text { Std. Dev. }\end{array}$ & $\begin{array}{c}4,4 \\
15 \\
1,4 \\
\end{array}$ & $\begin{array}{c}1,5 \\
15 \\
, 6\end{array}$ & $\begin{array}{c}1,9 \\
15 \\
1,4 \\
\end{array}$ & $\begin{array}{c}1,9 \\
15 \\
1,3\end{array}$ \\
\hline arab league & $\begin{array}{l}\text { Mean } \\
N \\
\text { Std. Dev. }\end{array}$ & $\begin{array}{c}3,3 \\
12 \\
3,3 \\
\end{array}$ & $\begin{array}{c}1,8 \\
15 \\
2,3 \\
\end{array}$ & $\begin{array}{c}-, 7 \\
13 \\
2,2 \\
\end{array}$ & $\begin{array}{c}13^{, 9} \\
2,1 \\
\end{array}$ \\
\hline sadc & $\begin{array}{l}\text { Mean } \\
\mathrm{N} \\
\text { Std. Dev. }\end{array}$ & $\begin{array}{l}2,9 \\
9 \\
, 8\end{array}$ & $\begin{array}{c}10^{.6} \\
3,1\end{array}$ & $\begin{array}{c}1,1 \\
12 \\
2,9\end{array}$ & $\begin{array}{l}-., 4 \\
12^{-0} \\
4.0\end{array}$ \\
\hline ecowas & $\begin{array}{l}\text { Mean } \\
\mathrm{N} \\
\text { Std. Dev. }\end{array}$ & $\begin{array}{c}1,5 \\
10 \\
1,9 \\
\end{array}$ & $\begin{array}{c}-, 6 \\
12 \\
1,4 \\
\end{array}$ & $\begin{array}{c}-, 8 \\
11 \\
2,1 \\
\end{array}$ & $\begin{array}{c}11^{.1} \\
2,3 \\
\end{array}$ \\
\hline cacm & $\begin{array}{l}\text { Mean } \\
\mathrm{N} \\
\text { Std. Dev. }\end{array}$ & $\begin{array}{l}2,8 \\
4 \\
, 7\end{array}$ & $\begin{array}{c}-1,9 \\
5 \\
1,7\end{array}$ & $\begin{array}{l}-, 2 \\
5 \\
3,6\end{array}$ & $\begin{array}{l}2,0 \\
5 \\
.7\end{array}$ \\
\hline andean & $\begin{array}{l}\text { Mean } \\
\mathrm{N} \\
\text { Std. Dev. }\end{array}$ & $\begin{array}{l}2,2 \\
5 \\
, 3\end{array}$ & $\begin{array}{l}-, 7 \\
5 \\
2,1\end{array}$ & $\begin{array}{l}, 6 \\
5 \\
1,8\end{array}$ & $\begin{array}{l}1,7 \\
5 \\
1,5\end{array}$ \\
\hline cis & $\begin{array}{l}\text { Mean } \\
N \\
\text { Std. Dev. }\end{array}$ & & & $\begin{array}{c}-7,5 \\
11 \\
5,6\end{array}$ & $\begin{array}{c}-8,6 \\
12 \\
4,0\end{array}$ \\
\hline apec & $\begin{array}{l}\text { Mean } \\
\mathrm{N} \\
\text { Std. Dev. }\end{array}$ & $\begin{array}{c}4,2 \\
19 \\
2,3 \\
\end{array}$ & $\begin{array}{c}2,6 \\
17 \\
2,5 \\
\end{array}$ & $\begin{array}{c}3,2 \\
18 \\
3,6 \\
\end{array}$ & $\begin{array}{c}3,1 \\
19 \\
3,5 \\
\end{array}$ \\
\hline nordic & $\begin{array}{l}\text { Mean } \\
N \\
\text { Std. Dev. }\end{array}$ & $\begin{array}{l}3,9 \\
5 \\
, 5\end{array}$ & $\begin{array}{l}1,8 \\
5 \\
, 9\end{array}$ & $\begin{array}{l}5^{.5} \\
.8\end{array}$ & $\begin{array}{l}2,0 \\
5 \\
1,2\end{array}$ \\
\hline $\begin{array}{l}\text { org islamic } \\
\text { conf }\end{array}$ & $\begin{array}{l}\text { Mean } \\
N \\
\text { Std. Dev. }\end{array}$ & $\begin{array}{c}2,6 \\
32 \\
2,7 \\
\end{array}$ & $\begin{array}{c}1,3 \\
32 \\
2,1 \\
\end{array}$ & $\begin{array}{l}-1,2 \\
41 \\
3,9 \\
\end{array}$ & $\begin{array}{c}-, 5 \\
41^{-, 5} \\
4,7 \\
\end{array}$ \\
\hline Total & $\begin{array}{l}\text { Mean } \\
\mathrm{N} \\
\text { Std. Dev. } \\
\text { Eta sq. } \\
\text { Sig. }\end{array}$ & $\begin{array}{r}3,1 \\
127 \\
2,3 \\
, 1 \\
, 1\end{array}$ & $\begin{array}{r}1,3 \\
129 \\
2,3 \\
.3 \\
.0\end{array}$ & $\begin{array}{r}149 \\
149 \\
4,2 \\
, 4 \\
, 0\end{array}$ & $\begin{array}{r}154^{.3} \\
4,4 \\
, 5 \\
.0\end{array}$ \\
\hline
\end{tabular}

Source: By the author. 
Appendix 4 Openness (IMPEX) 1975-98

\begin{tabular}{|c|c|c|c|c|c|c|}
\hline Group & & $\underset{75}{\text { impex }}$ & $\begin{array}{c}\text { Impex } \\
80\end{array}$ & $\begin{array}{c}\text { Impex } \\
90\end{array}$ & $\begin{array}{c}\text { Impex } \\
98\end{array}$ & $\begin{array}{l}\text { impex } \\
75-98\end{array}$ \\
\hline Nafta & $\begin{array}{l}\text { Mean } \\
\text { N } \\
\text { Std. Dev. }\end{array}$ & $\begin{array}{c}26,6 \\
3 \\
17,7\end{array}$ & $\begin{array}{c}33,1 \\
3 \\
18,7\end{array}$ & $\begin{array}{c}37,2 \\
3 \\
15,5\end{array}$ & $\begin{array}{c}64,5 \\
1 \\
,\end{array}$ & $\begin{array}{c}36,8 \\
3 \\
18,1\end{array}$ \\
\hline Mercosur & $\begin{array}{l}\text { Mean } \\
\mathrm{N} \\
\text { Std. Dev. }\end{array}$ & $\begin{array}{c}25 \\
4 \\
11,6 \\
\end{array}$ & $\begin{array}{c}27,9 \\
4 \\
14,7\end{array}$ & $\begin{array}{c}31,9 \\
4 \\
19,5\end{array}$ & $\begin{array}{c}44,9 \\
4 \\
35 \\
\end{array}$ & $\begin{array}{c}34 \\
4 \\
21,2\end{array}$ \\
\hline asean & $\begin{array}{l}\text { Mean } \\
\mathrm{N} \\
\text { Std. Dev. }\end{array}$ & $\begin{array}{c}89,3 \\
6 \\
107,1\end{array}$ & $\begin{array}{c}122,4 \\
6 \\
157,9\end{array}$ & $\begin{array}{c}95,1 \\
9 \\
120,5\end{array}$ & $\begin{array}{c}127,9 \\
7 \\
91,5\end{array}$ & $\begin{array}{c}91,6 \\
9 \\
105,6\end{array}$ \\
\hline eu & $\begin{array}{l}\text { Mean } \\
\mathrm{N} \\
\text { Std. Dev. }\end{array}$ & $\begin{array}{l}67,6 \\
14 \\
39,0\end{array}$ & $\begin{array}{l}75,20 \\
14 \\
38,9\end{array}$ & $\begin{array}{l}78,2 \\
14 \\
45,4\end{array}$ & & $\begin{array}{l}74,7 \\
15 \\
40,7\end{array}$ \\
\hline arab league & $\begin{array}{l}\text { Mean } \\
\mathrm{N} \\
\text { Std. Dev. }\end{array}$ & $\begin{array}{l}76,8 \\
13 \\
27,1\end{array}$ & $\begin{array}{l}86,6 \\
14 \\
29,2 \\
\end{array}$ & $\begin{array}{l}80,3 \\
14 \\
34,1\end{array}$ & $\begin{array}{l}73,7 \\
11 \\
25 \\
\end{array}$ & $\begin{array}{l}77,1 \\
16 \\
25,7 \\
\end{array}$ \\
\hline sadc & $\begin{array}{l}\text { Mean } \\
\mathrm{N} \\
\text { Std. Dev. }\end{array}$ & $\begin{array}{c}77,1 \\
8 \\
32\end{array}$ & $\begin{array}{l}83,4 \\
10 \\
40,7\end{array}$ & $\begin{array}{l}76,2 \\
12 \\
34,9\end{array}$ & $\begin{array}{l}86,2 \\
11 \\
38,3\end{array}$ & $\begin{array}{l}78,5 \\
12 \\
35,2\end{array}$ \\
\hline ecowas & $\begin{array}{l}\text { Mean } \\
\mathrm{N} \\
\text { Std. Dev. }\end{array}$ & $\begin{array}{l}60,3 \\
11 \\
24,6 \\
\end{array}$ & $\begin{array}{l}62,9 \\
11 \\
27,8 \\
\end{array}$ & $\begin{array}{l}53,6 \\
11 \\
13,7 \\
\end{array}$ & $\begin{array}{l}58,3 \\
11 \\
13,4 \\
\end{array}$ & $\begin{array}{l}59,4 \\
12 \\
20,4 \\
\end{array}$ \\
\hline cacm & $\begin{array}{l}\text { Mean } \\
\mathrm{N} \\
\text { Std. Dev. }\end{array}$ & $\begin{array}{c}64,1 \\
5 \\
10,8\end{array}$ & $\begin{array}{c}65,1 \\
5 \\
11,9\end{array}$ & $\begin{array}{c}63,8 \\
5 \\
14,8\end{array}$ & $\begin{array}{c}82,5 \\
5 \\
28,5\end{array}$ & $\begin{array}{c}62,8 \\
5 \\
14,2\end{array}$ \\
\hline andean & $\begin{array}{l}\text { Mean } \\
\mathrm{N} \\
\text { Std. Dev. }\end{array}$ & $\begin{array}{c}49,4 \\
5 \\
18,3\end{array}$ & $\begin{array}{c}44,6 \\
5 \\
7,7\end{array}$ & $\begin{array}{c}45,2 \\
5 \\
15,7\end{array}$ & $\begin{array}{c}42,5 \\
5 \\
13,0\end{array}$ & $\begin{array}{c}43,6 \\
5 \\
11,2\end{array}$ \\
\hline cis & $\begin{array}{l}\text { Mean } \\
\mathrm{N} \\
\text { Std. Dev. }\end{array}$ & & & $\begin{array}{c}75,7 \\
8 \\
20,3\end{array}$ & $\begin{array}{l}78,7 \\
10 \\
29,3\end{array}$ & $\begin{array}{l}92,8 \\
11 \\
34,2\end{array}$ \\
\hline apec & $\begin{array}{l}\text { Mean } \\
\mathrm{N} \\
\text { Std. Dev. }\end{array}$ & $\begin{array}{l}65,9 \\
17 \\
71\end{array}$ & $\begin{array}{c}82,1 \\
17 \\
100,4\end{array}$ & $\begin{array}{l}83,2 \\
19 \\
94,2\end{array}$ & $\begin{array}{c}117,6 \\
13 \\
82\end{array}$ & $\begin{array}{l}79,3 \\
19 \\
82,8\end{array}$ \\
\hline nordic & $\begin{array}{l}\text { Mean } \\
\mathrm{N} \\
\text { Std. Dev. }\end{array}$ & $\begin{array}{c}65 \\
5 \\
10,9\end{array}$ & $\begin{array}{c}69,2 \\
5 \\
7,1\end{array}$ & $\begin{array}{c}63,1 \\
5 \\
10,2\end{array}$ & & $\begin{array}{l}66,5 \\
5 \\
6,3\end{array}$ \\
\hline $\begin{array}{l}\text { org islamic } \\
\text { conf }\end{array}$ & $\begin{array}{l}\text { Mean } \\
\mathrm{N} \\
\text { Std. Dev. }\end{array}$ & $\begin{array}{l}61,1 \\
33 \\
29,1\end{array}$ & $\begin{array}{l}67,8 \\
35 \\
30,9\end{array}$ & $\begin{array}{l}63,9 \\
38 \\
31,7\end{array}$ & $\begin{array}{l}65,7 \\
37 \\
32,7\end{array}$ & $\begin{array}{l}66,9 \\
44 \\
31,8\end{array}$ \\
\hline Total & $\begin{array}{l}\text { Mean } \\
\mathrm{N} \\
\text { Std. Dev. } \\
\text { Eta sq } \\
\text { Sig. }\end{array}$ & $\begin{array}{c}64,3 \\
124 \\
43,2 \\
.1 \\
, 6\end{array}$ & $\begin{array}{c}72,9 \\
129 \\
56,8 \\
, 1 \\
, 4\end{array}$ & $\begin{array}{c}70,0 \\
147 \\
52,7 \\
, 1 \\
, 6\end{array}$ & $\begin{array}{c}77,5 \\
115 \\
48,4 \\
, 2 \\
, 0\end{array}$ & $\begin{array}{c}71,4 \\
160 \\
46,9 \\
, 1 \\
.4\end{array}$ \\
\hline
\end{tabular}

Source: By the author. 
Appendix 5 Inflation: year to year

\begin{tabular}{|c|c|c|c|c|c|}
\hline Group & & INFL6173 & INFL7390 & INFL9098 & INFL9598 \\
\hline Nafta & \begin{tabular}{|l|} 
Mean \\
$\mathrm{N}$ \\
Std. Deviation
\end{tabular} & $\begin{array}{l}\begin{array}{l}3,4 \\
3 \\
, 35\end{array}\end{array}$ & $\begin{array}{c}20,4 \\
3 \\
23,2\end{array}$ & $\begin{array}{c}8,7 \\
3 \\
10,5\end{array}$ & $\begin{array}{c}10,2 \\
3 \\
14,1\end{array}$ \\
\hline Mercosur & \begin{tabular}{|l|} 
Mean \\
$\mathrm{N}$ \\
Std. Deviation
\end{tabular} & $\begin{array}{c}28,4 \\
3 \\
23,7\end{array}$ & $\begin{array}{c}198,1 \\
3 \\
271,7\end{array}$ & $\begin{array}{c}322,2 \\
4 \\
425,8\end{array}$ & $\begin{array}{c}15 \\
4 \\
11,3\end{array}$ \\
\hline asean & \begin{tabular}{|l|} 
Mean \\
$\mathrm{N}$ \\
Std. Deviation
\end{tabular} & $\begin{array}{c}31,0 \\
6 \\
65,8\end{array}$ & $\begin{array}{l}9,6 \\
6 \\
4,4\end{array}$ & $\begin{array}{c}12,6 \\
7 \\
10,2\end{array}$ & $\begin{array}{c}14,5 \\
8 \\
13,5\end{array}$ \\
\hline eu & \begin{tabular}{|l|} 
Mean \\
$\mathrm{N}$ \\
Std. Deviation
\end{tabular} & $\begin{array}{c}4,8 \\
15 \\
1,1\end{array}$ & $\begin{array}{c}9,5 \\
15 \\
4,6\end{array}$ & $\begin{array}{c}3,7 \\
15 \\
2,6\end{array}$ & $\begin{array}{c}2,3 \\
15 \\
1,5\end{array}$ \\
\hline arab league & \begin{tabular}{|l|} 
Mean \\
$N$ \\
Std. Deviation \\
\end{tabular} & $\begin{array}{l}3,6 \\
4 \\
1,0 \\
\end{array}$ & $\begin{array}{c}13,0 \\
8 \\
8,4 \\
\end{array}$ & $\begin{array}{c}16,1 \\
8 \\
29,0 \\
\end{array}$ & $\begin{array}{l}11,8 \\
10 \\
20,4 \\
\end{array}$ \\
\hline sadc & $\begin{array}{l}\text { Mean } \\
\mathrm{N} \\
\text { Std. Deviation } \\
\end{array}$ & $\begin{array}{l}3,8 \\
1 \\
\end{array}$ & $\begin{array}{c}23,7 \\
5 \\
19,2 \\
\end{array}$ & $\begin{array}{c}17,0 \\
7 \\
9,1 \\
\end{array}$ & $\begin{array}{c}411,2 \\
8 \\
1116,6 \\
\end{array}$ \\
\hline ecowas & \begin{tabular}{|l|} 
Mean \\
$\mathrm{N}$ \\
Std. Deviation
\end{tabular} & $\begin{array}{l}4,3 \\
3 \\
, 8\end{array}$ & $\begin{array}{c}21,2 \\
7 \\
18,8\end{array}$ & $\begin{array}{c}16,0 \\
9 \\
16,2\end{array}$ & $\begin{array}{l}13,4 \\
10 \\
12,4\end{array}$ \\
\hline cacm & \begin{tabular}{|l|} 
Mean \\
$\mathrm{N}$ \\
Std. Deviation
\end{tabular} & $\begin{array}{l}2,3 \\
4 \\
1,1\end{array}$ & $\begin{array}{c}284,6 \\
5 \\
603\end{array}$ & $\begin{array}{c}16,5 \\
4 \\
3,7\end{array}$ & $\begin{array}{l}13,5 \\
4 \\
6.9\end{array}$ \\
\hline andean & \begin{tabular}{|l|} 
Mean \\
$\mathrm{N}$ \\
Std. Deviation
\end{tabular} & $\begin{array}{l}7,2 \\
5 \\
3,9\end{array}$ & $\begin{array}{c}308,6 \\
5 \\
392,2\end{array}$ & $\begin{array}{c}204 \\
5 \\
387,8\end{array}$ & $\begin{array}{c}25,7 \\
5 \\
21,6\end{array}$ \\
\hline cis & \begin{tabular}{|l|} 
Mean \\
$N$ \\
Std. Deviation
\end{tabular} & & & & $\begin{array}{c}79,3 \\
6 \\
74,1\end{array}$ \\
\hline apec & \begin{tabular}{|l|} 
Mean \\
$\mathrm{N}$ \\
Std. Deviation
\end{tabular} & $\begin{array}{l}20,8 \\
13 \\
45,7\end{array}$ & $\begin{array}{c}63,5 \\
15 \\
177,0\end{array}$ & $\begin{array}{c}62,6 \\
16 \\
222,7\end{array}$ & $\begin{array}{l}10,8 \\
18 \\
16,7\end{array}$ \\
\hline nordic & \begin{tabular}{|l|} 
Mean \\
$\mathrm{N}$ \\
Std. Deviation
\end{tabular} & $\begin{array}{l}6,7 \\
5 \\
3\end{array}$ & $\begin{array}{c}14,3 \\
5 \\
12,9\end{array}$ & $\begin{array}{l}3 \\
5 \\
1\end{array}$ & $\begin{array}{l}1,6 \\
5 \\
, 6\end{array}$ \\
\hline $\begin{array}{l}\text { org islamic } \\
\text { conf }\end{array}$ & \begin{tabular}{|l|} 
Mean \\
$\mathrm{N}$ \\
Std. Deviation
\end{tabular} & $\begin{array}{l}17,4 \\
12 \\
46,6\end{array}$ & $\begin{array}{l}17,8 \\
21 \\
11,6\end{array}$ & $\begin{array}{l}16,9 \\
24 \\
23\end{array}$ & $\begin{array}{l}16 \\
29 \\
20,9\end{array}$ \\
\hline Total & \begin{tabular}{|l} 
Mean \\
$\mathrm{N}$ \\
Std. Deviation \\
Eta sq. \\
Sig.
\end{tabular} & $\begin{array}{l}12,8 \\
74 \\
32,7 \\
, 1 \\
, 9\end{array}$ & $\begin{array}{r}56,4 \\
98 \\
188,0 \\
, 2\end{array}$ & $\begin{array}{l}40,7 \\
107 \\
151,6 \\
, 2\end{array}$ & $\begin{array}{r}40,8 \\
125 \\
283,7 \\
, 1 \\
, 2\end{array}$ \\
\hline
\end{tabular}

Source: By the author. 
Appendix 6 Perceived corruption scores 1998-2002

\begin{tabular}{|c|c|c|c|c|c|c|}
\hline Group & & CORR98 & CORR99 & CORROO & CORR01 & CORR02 \\
\hline Nafta & $\begin{array}{l}\text { Mean } \\
N \\
\text { Std. Dev. }\end{array}$ & $\begin{array}{l}3,3 \\
3 \\
3,0 \\
\end{array}$ & $\begin{array}{l}3,3 \\
3 \\
3 \\
\end{array}$ & $\begin{array}{l}3,2 \\
3 \\
3,1 \\
\end{array}$ & $\begin{array}{l}3,3 \\
3 \\
2,7 \\
\end{array}$ & $\begin{array}{l}4,1 \\
3 \\
2,8 \\
\end{array}$ \\
\hline Mercusor & $\begin{array}{l}\text { Mean } \\
\mathrm{N} \\
\text { Std. Dev. }\end{array}$ & $\begin{array}{l}6,8 \\
4 \\
1,3 \\
\end{array}$ & $\begin{array}{l}6,6 \\
4 \\
1,1\end{array}$ & $\begin{array}{l}6,3 \\
2 \\
, 3\end{array}$ & $\begin{array}{l}5,8 \\
3 \\
, 8\end{array}$ & $\begin{array}{l}6 \\
4 \\
2,6\end{array}$ \\
\hline asean & $\begin{array}{l}\text { Mean } \\
\mathrm{N} \\
\text { Std. Dev. }\end{array}$ & $\begin{array}{l}5,8 \\
6 \\
2,7\end{array}$ & $\begin{array}{l}5,8 \\
6 \\
2,6\end{array}$ & $\begin{array}{l}6 \\
6 \\
2,7 \\
\end{array}$ & $\begin{array}{l}5,9 \\
6 \\
2,7 \\
\end{array}$ & $\begin{array}{l}6 \\
6 \\
2,8\end{array}$ \\
\hline eu & $\begin{array}{l}\text { Mean } \\
\mathrm{N} \\
\text { Std. Dev. }\end{array}$ & $\begin{array}{c}2,4 \\
15 \\
1,8 \\
\end{array}$ & $\begin{array}{c}2,4 \\
15 \\
1,7\end{array}$ & $\begin{array}{c}2,4 \\
15 \\
1,7\end{array}$ & $\begin{array}{c}2,5 \\
15 \\
1,6\end{array}$ & $\begin{array}{c}2,4 \\
15 \\
1,6\end{array}$ \\
\hline arab league & $\begin{array}{l}\text { Mean } \\
\mathrm{N} \\
\text { Std. Dev. }\end{array}$ & $\begin{array}{l}5,9 \\
4 \\
1 \\
\end{array}$ & $\begin{array}{l}5,8 \\
4 \\
, 8 \\
\end{array}$ & $\begin{array}{l}5,6 \\
4 \\
.9 \\
\end{array}$ & $\begin{array}{l}5,4 \\
3 \\
, 9 \\
\end{array}$ & $\begin{array}{l}5,9 \\
4 \\
.7\end{array}$ \\
\hline sadc & $\begin{array}{l}\text { Mean } \\
\text { N } \\
\text { Std. Dev. }\end{array}$ & $\begin{array}{l}5,6 \\
8 \\
1,3 \\
\end{array}$ & $\begin{array}{l}5,7 \\
9 \\
1,2 \\
\end{array}$ & $\begin{array}{c}6,2 \\
10 \\
1,5\end{array}$ & $\begin{array}{l}6,1 \\
8 \\
1,4 \\
\end{array}$ & $\begin{array}{l}6,2 \\
9 \\
1,6 \\
\end{array}$ \\
\hline ecowas & $\begin{array}{l}\text { Mean } \\
\mathrm{N} \\
\text { Std. Dev. }\end{array}$ & $\begin{array}{l}7,1 \\
4 \\
, 67\end{array}$ & $\begin{array}{l}7,3 \\
4 \\
, 8 \\
\end{array}$ & $\begin{array}{l}7,2 \\
5 \\
, 9 \\
\end{array}$ & $\begin{array}{l}7,6 \\
4 \\
1,0 \\
\end{array}$ & $\begin{array}{l}7,2 \\
4 \\
1 \\
\end{array}$ \\
\hline cacm & $\begin{array}{l}\text { Mean } \\
\text { N } \\
\text { Std. Dev. }\end{array}$ & $\begin{array}{l}6,6 \\
5 \\
1,4 \\
\end{array}$ & $\begin{array}{l}6,6 \\
5 \\
1,2 \\
\end{array}$ & $\begin{array}{l}5,3 \\
2 \\
, 9\end{array}$ & $\begin{array}{l}6,8 \\
5 \\
, 8 \\
\end{array}$ & $\begin{array}{l}6,9 \\
5 \\
, 9\end{array}$ \\
\hline andean & $\begin{array}{l}\text { Mean } \\
\mathrm{N} \\
\text { Std. Dev. }\end{array}$ & $\begin{array}{l}7,2 \\
5 \\
1\end{array}$ & $\begin{array}{l}7, \\
5 \\
, 9\end{array}$ & $\begin{array}{l}6,9 \\
5 \\
, 8\end{array}$ & $\begin{array}{l}7,0 \\
5 \\
, 9\end{array}$ & $\begin{array}{l}7,1 \\
5 \\
, 8\end{array}$ \\
\hline cis & $\begin{array}{l}\text { Mean } \\
\mathrm{N} \\
\text { Std. Dev. }\end{array}$ & $\begin{array}{l}7 \\
3 \\
, 8 \\
\end{array}$ & $\begin{array}{c}7,6 \\
10 \\
, 5 \\
\end{array}$ & $\begin{array}{l}7,5 \\
8 \\
, 8 \\
\end{array}$ & $\begin{array}{l}7,5 \\
6 \\
, 4\end{array}$ & $\begin{array}{l}7,3 \\
8 \\
, 9\end{array}$ \\
\hline apec & $\begin{array}{l}\text { Mean } \\
\mathrm{N} \\
\text { Std. Dev. }\end{array}$ & $\begin{array}{c}4,5 \\
19 \\
2,5\end{array}$ & $\begin{array}{c}4,5 \\
19 \\
2,6\end{array}$ & $\begin{array}{c}4,6 \\
19 \\
2,6\end{array}$ & $\begin{array}{c}4,5 \\
19 \\
2,6\end{array}$ & $\begin{array}{c}4,6 \\
19 \\
2,6\end{array}$ \\
\hline nordic & $\begin{array}{l}\text { Mean } \\
\mathrm{N} \\
\text { Std. Dev. }\end{array}$ & $5^{.5}$ & $\begin{array}{l}5^{.5} \\
.4 \\
\end{array}$ & $5^{.5}$ & $5^{.8}$ & $\begin{array}{l}5^{, 7} \\
, 5\end{array}$ \\
\hline $\begin{array}{l}\text { org islamic } \\
\text { conf }\end{array}$ & $\begin{array}{l}\text { Mean } \\
\mathrm{N} \\
\text { Std. Dev. }\end{array}$ & $\begin{array}{c}6,8 \\
13 \\
1,2 \\
\end{array}$ & $\begin{array}{c}7,1 \\
19 \\
1,2 \\
\end{array}$ & $\begin{array}{c}7 \\
17 \\
1,2\end{array}$ & $\begin{array}{c}7,2 \\
16 \\
1,4\end{array}$ & $\begin{array}{c}7,1 \\
18 \\
1,1\end{array}$ \\
\hline Total & $\begin{array}{l}\text { Mean } \\
\text { N } \\
\text { Std. Dev. } \\
\text { Eta sq } \\
\text { Sig }\end{array}$ & $\begin{array}{c}5,0 \\
94 \\
2,6 \\
, 6 \\
, 0\end{array}$ & $\begin{array}{r}5,4 \\
108 \\
2,5 \\
, 6 \\
.0\end{array}$ & $\begin{array}{r}5,2 \\
101 \\
2,6 \\
, 6 \\
, 0\end{array}$ & $\begin{array}{c}5,2 \\
98 \\
2,6 \\
.6 \\
.0\end{array}$ & $\begin{array}{c}5,4 \\
105 \\
2,6 \\
, 6 \\
, 0\end{array}$ \\
\hline
\end{tabular}

Source: By the author. 
Appendix 7 Human development index: 1975-1999

\begin{tabular}{|c|c|c|c|c|c|c|c|}
\hline Group & & HDI1975 & HDI1980 & HDI1985 & HDI1990 & HDI1995 & HDI1999 \\
\hline Nafta & $\begin{array}{l}\text { Mean } \\
\mathrm{N} \\
\text { Std. Dev. }\end{array}$ & $3^{.8}$ & $3^{, 8}$ & $3^{, 9}$ & $3^{.9}$ & $3^{.9}$ & $3^{.9}$ \\
\hline Mercosur & $\begin{array}{l}\text { Mean } \\
\mathrm{N} \\
\text { Std. Dev. }\end{array}$ & $4^{.7}$ & $4^{.7}$ & $4^{.7}$ & $\begin{array}{l}4^{, 8} \\
, 1 \\
\end{array}$ & $\begin{array}{l}4^{, 8} \\
, 1 \\
\end{array}$ & $4^{, 8}, 1$ \\
\hline asean & $\begin{array}{l}\text { Mean } \\
\mathrm{N} \\
\text { Std. Dev. }\end{array}$ & $5^{.6}$ & $\begin{array}{l}.7 \\
.1 \\
\end{array}$ & $\begin{array}{l}7^{, 6} \\
.1 \\
\end{array}$ & $7^{, 7}$ & $7^{, 7}$ & $\begin{array}{l}9^{, 7} \\
.1 \\
\end{array}$ \\
\hline eu & $\begin{array}{l}\text { Mean } \\
\mathrm{N} \\
\text { Std. Dev. }\end{array}$ & $14^{.8}$ & $14^{, 8}$ & $14^{, 9}$ & $14^{, 9}$ & $15^{, 9}$ & $15^{99}$ \\
\hline arab league & $\begin{array}{l}\text { Mean } \\
\mathrm{N} \\
\text { Std. Dev. }\end{array}$ & $7^{, 5}$ & $\begin{array}{l}8^{, 5} \\
.1 \\
\end{array}$ & $8^{.6}$ & $9^{.6}$ & $9^{.6}$ & $15^{.7}$ \\
\hline sadc & $\begin{array}{l}\text { Mean } \\
\mathrm{N} \\
\text { Std. Dev. }\end{array}$ & $\begin{array}{l}7^{.5} \\
.1 \\
\end{array}$ & $9^{, 5}$ & $9^{, 5}$ & $\begin{array}{r}10^{.5} \\
.1 \\
\end{array}$ & $10^{.5}$ & $12^{.5}$ \\
\hline ecowas & $\begin{array}{l}\text { Mean } \\
\mathrm{N} \\
\text { Std. Dev. }\end{array}$ & $9^{, 3}$ & $9^{, 3}$ & $9^{.4}$ & $9^{.4}$ & $9^{.4}$ & $\begin{array}{r}11^{, 4} \\
, 1 \\
\end{array}$ \\
\hline cacm & $\begin{array}{l}\text { Mean } \\
\mathrm{N} \\
\text { Std. Dev. }\end{array}$ & $5^{.6}$ & $\begin{array}{l}5^{, 6} \\
.1 \\
\end{array}$ & $5^{.6}$ & $5^{.6}$ & $5_{.1}^{.7}$ & $\begin{array}{l}5^{, 7} \\
, 1\end{array}$ \\
\hline andean & $\begin{array}{l}\text { Mean } \\
\mathrm{N} \\
\text { Std. Dev. }\end{array}$ & $\begin{array}{l}5^{, 6} \\
.07 \\
\end{array}$ & $5^{.7}$ & $\begin{array}{l}.7 \\
.1 \\
\end{array}$ & $\begin{array}{l}.7 \\
5^{, 1} \\
\end{array}$ & $5^{, 7}$ & $5^{.7}$ \\
\hline cis & $\begin{array}{l}\text { Mean } \\
\mathrm{N} \\
\text { Std. Dev. }\end{array}$ & & $1^{.8}$ & $1^{.8}$ & $\begin{array}{l}5^{, 8} \\
.1 \\
\end{array}$ & $5^{.7}$ & $12^{, 7}$ \\
\hline apec & $\begin{array}{l}\text { Mean } \\
\mathrm{N} \\
\text { Std. Dev. }\end{array}$ & $\begin{array}{r}17^{, 7} \\
.1 \\
\end{array}$ & $\begin{array}{r}18^{, 7} \\
, 1 \\
\end{array}$ & $\begin{array}{c}19^{.7} \\
.1 \\
\end{array}$ & $19^{.8}$ & $19^{.8}$ & $\begin{array}{c}19^{.8} \\
.1 \\
\end{array}$ \\
\hline nordic & $\begin{array}{l}\text { Mean } \\
\mathrm{N} \\
\text { Std. Dev. }\end{array}$ & $5^{.9}$ & $5^{.9}$ & $5^{, 9}$ & $5^{.9}$ & $5^{.9}$ & $5^{.9}$ \\
\hline $\begin{array}{l}\text { org islamic } \\
\text { conf }\end{array}$ & $\begin{array}{l}\text { Mean } \\
\mathrm{N} \\
\text { Std. Dev. }\end{array}$ & $23^{.4}$ & $26^{.5}$ & $27^{, 5}$ & $\begin{array}{r}29^{, 5} \\
, 2 \\
\end{array}$ & $29^{, 5}$ & $43^{, 6}$ \\
\hline Total & $\begin{array}{l}\text { Mean } \\
\mathrm{N} \\
\text { Std. Dev. } \\
\text { Eta sq. } \\
\text { Sig. }\end{array}$ & $\begin{array}{r}104^{, 6} \\
.2 \\
8\end{array}$ & $\begin{array}{r}112^{, 6} \\
, 2 \\
.7\end{array}$ & $\begin{array}{r}1166^{, 6} \\
, 2 \\
.7\end{array}$ & $\begin{array}{r}124^{, 7} \\
, 2 \\
.7\end{array}$ & $\begin{array}{r}125^{, 7} \\
, 2 \\
, 7\end{array}$ & $\begin{array}{r}158^{.7} \\
, 2 \\
6\end{array}$ \\
\hline
\end{tabular}

Source: By the author. 
Appendix 8 Economic freedom scores 1975-1999

\begin{tabular}{|c|c|c|c|c|c|c|c|}
\hline Group & & $\begin{array}{c}\text { ECFR } \\
1975\end{array}$ & $\begin{array}{c}\text { ECFR } \\
1980\end{array}$ & $\begin{array}{c}\text { ECFR } \\
1985\end{array}$ & $\begin{array}{c}\text { ECFR } \\
1990\end{array}$ & $\begin{array}{c}\text { ECFR } \\
1995\end{array}$ & $\begin{array}{c}\text { ECFR } \\
1999\end{array}$ \\
\hline nafta & $\begin{array}{l}\text { Mean } \\
\mathrm{N} \\
\text { Std. Dev. }\end{array}$ & $\begin{array}{l}7 \\
3 \\
1,3 \\
\end{array}$ & $\begin{array}{l}7,1 \\
3 \\
1,8 \\
\end{array}$ & $\begin{array}{l}7,2 \\
3 \\
2 \\
\end{array}$ & $\begin{array}{l}7,9 \\
3 \\
1,2 \\
\end{array}$ & $\begin{array}{l}7,9 \\
3 \\
, 9\end{array}$ & $\begin{array}{l}7,8 \\
3 \\
1,2 \\
\end{array}$ \\
\hline mercosur & $\begin{array}{l}\text { Mean } \\
\mathrm{N} \\
\text { Std. Dev. }\end{array}$ & $\begin{array}{l}4,6 \\
3 \\
1,6 \\
\end{array}$ & $\begin{array}{l}5,3 \\
4 \\
1,0 \\
\end{array}$ & $\begin{array}{l}4,7 \\
4 \\
1,5 \\
\end{array}$ & $\begin{array}{l}5,6 \\
4 \\
1,1 \\
\end{array}$ & $\begin{array}{l}6,7 \\
4 \\
1,2 \\
\end{array}$ & $\begin{array}{l}6,9 \\
4 \\
1,3 \\
\end{array}$ \\
\hline asean & $\begin{array}{l}\text { Mean } \\
\mathrm{N} \\
\text { Std. Dev. }\end{array}$ & $\begin{array}{l}5,8 \\
5 \\
1,2 \\
\end{array}$ & $\begin{array}{l}5,6 \\
6 \\
1,9\end{array}$ & $\begin{array}{l}5,8 \\
6 \\
2,1\end{array}$ & $\begin{array}{l}6,1 \\
6 \\
2,6\end{array}$ & $\begin{array}{l}6,7 \\
6 \\
2,4\end{array}$ & $\begin{array}{l}6,4 \\
6 \\
2,5\end{array}$ \\
\hline eu & $\begin{array}{l}\text { Mean } \\
\mathrm{N} \\
\text { Std. Dev. }\end{array}$ & $\begin{array}{c}6,3 \\
15 \\
1,3 \\
\end{array}$ & $\begin{array}{c}6,7 \\
15 \\
.9 \\
\end{array}$ & $\begin{array}{c}6,9 \\
15 \\
1,0 \\
\end{array}$ & $\begin{array}{c}7,5 \\
15 \\
.7 \\
\end{array}$ & $\begin{array}{c}8 \\
15 \\
.4 \\
\end{array}$ & $\begin{array}{c}8,0 \\
15 \\
.4 \\
\end{array}$ \\
\hline arab league & $\begin{array}{l}\text { Mean } \\
\mathrm{N} \\
\text { Std. Dev. }\end{array}$ & $\begin{array}{l}4,8 \\
5 \\
, 5 \\
\end{array}$ & $\begin{array}{l}4,8 \\
9 \\
1 \\
\end{array}$ & $\begin{array}{l}5,3 \\
9 \\
1,6 \\
\end{array}$ & $\begin{array}{l}4,9 \\
9 \\
1,7 \\
\end{array}$ & $\begin{array}{l}5,5 \\
8 \\
1,4 \\
\end{array}$ & $\begin{array}{l}6,1 \\
9 \\
1,6 \\
\end{array}$ \\
\hline sadc & $\begin{array}{l}\text { Mean } \\
\mathrm{N} \\
\text { Std. Dev. }\end{array}$ & $\begin{array}{l}4,3 \\
7 \\
1,0\end{array}$ & $\begin{array}{l}4,5 \\
8 \\
, 9\end{array}$ & $\begin{array}{l}4,6 \\
8 \\
1,1\end{array}$ & $\begin{array}{l}4,6 \\
9 \\
1,1\end{array}$ & $\begin{array}{l}5,4 \\
9 \\
1,1\end{array}$ & $\begin{array}{l}5,9 \\
9 \\
1,4\end{array}$ \\
\hline ecowas & $\begin{array}{l}\text { Mean } \\
\mathrm{N} \\
\text { Std. Dev. }\end{array}$ & $\begin{array}{l}4,2 \\
6 \\
1,0 \\
\end{array}$ & $\begin{array}{l}4,3 \\
9 \\
1,2 \\
\end{array}$ & $\begin{array}{l}4,5 \\
9 \\
1,1 \\
\end{array}$ & $\begin{array}{l}4,5 \\
9 \\
, 7\end{array}$ & $\begin{array}{l}4,6 \\
9 \\
, 9\end{array}$ & $\begin{array}{l}4,9 \\
9 \\
, 7\end{array}$ \\
\hline cacm & $\begin{array}{l}\text { Mean } \\
\mathrm{N} \\
\text { Std. Dev. }\end{array}$ & $\begin{array}{l}7,5 \\
4 \\
, 5 \\
\end{array}$ & $\begin{array}{l}5 \\
5 \\
1,2 \\
\end{array}$ & $\begin{array}{l}4,3 \\
5 \\
1,6 \\
\end{array}$ & $\begin{array}{l}5,5 \\
5 \\
1,6 \\
\end{array}$ & $\begin{array}{l}7,1 \\
5 \\
, 9 \\
\end{array}$ & $\begin{array}{l}7,3 \\
5 \\
, 6 \\
\end{array}$ \\
\hline andean & $\begin{array}{l}\text { Mean } \\
\mathrm{N} \\
\text { Std. Dev. }\end{array}$ & $\begin{array}{l}5,0 \\
4 \\
1,4 \\
\end{array}$ & $\begin{array}{l}5 \\
5 \\
1,4 \\
\end{array}$ & $\begin{array}{l}4,4 \\
5 \\
1,4 \\
\end{array}$ & $\begin{array}{l}5,2 \\
5 \\
, 9\end{array}$ & $\begin{array}{l}6,2 \\
5 \\
1,4 \\
\end{array}$ & $\begin{array}{l}6,8 \\
5 \\
1,0 \\
\end{array}$ \\
\hline cis & $\begin{array}{l}\text { Mean } \\
\mathrm{N} \\
\text { Std. Dev. }\end{array}$ & $\begin{array}{l}1,6 \\
1\end{array}$ & $\begin{array}{l}1,6 \\
1\end{array}$ & $\begin{array}{l}1,6 \\
1\end{array}$ & $\begin{array}{l}1,5 \\
1\end{array}$ & $\begin{array}{l}3,8 \\
2 \\
1,4 \\
\end{array}$ & $\begin{array}{l}4,2 \\
2 \\
, 5 \\
\end{array}$ \\
\hline apec & $\begin{array}{l}\text { Mean } \\
\mathrm{N} \\
\text { Std. Dev. }\end{array}$ & $\begin{array}{c}5,7 \\
18 \\
1,9 \\
\end{array}$ & $\begin{array}{c}6,0 \\
19 \\
2 \\
\end{array}$ & $\begin{array}{c}6,2 \\
19 \\
2,00 \\
\end{array}$ & $\begin{array}{c}6,8 \\
19 \\
2 \\
\end{array}$ & $\begin{array}{c}7,5 \\
19 \\
1,3\end{array}$ & $\begin{array}{c}7,3 \\
19 \\
1,5 \\
\end{array}$ \\
\hline nordic & $\begin{array}{l}\text { Mean } \\
\mathrm{N} \\
\text { Std. Dev. }\end{array}$ & $\begin{array}{l}5,5 \\
5 \\
1,0\end{array}$ & $\begin{array}{l}6,2 \\
5 \\
, 6\end{array}$ & $\begin{array}{l}6,6 \\
5 \\
, 6\end{array}$ & $\begin{array}{l}7,5 \\
5 \\
, 2\end{array}$ & $\begin{array}{l}7,9 \\
5 \\
, 1\end{array}$ & $\begin{array}{l}8 \\
5 \\
, 1\end{array}$ \\
\hline $\begin{array}{l}\text { org islamic } \\
\text { conf }\end{array}$ & $\begin{array}{l}\text { Mean } \\
\mathrm{N} \\
\text { Std. Dev. }\end{array}$ & $\begin{array}{c}4,6 \\
16 \\
1,0\end{array}$ & $\begin{array}{c}4,5 \\
26 \\
1,1\end{array}$ & $\begin{array}{c}5 \\
27 \\
1,3\end{array}$ & $\begin{array}{c}4,7 \\
28 \\
1,4\end{array}$ & $\begin{array}{c}5,2 \\
27 \\
1,2\end{array}$ & $\begin{array}{c}5,4 \\
28 \\
1,2\end{array}$ \\
\hline Total & $\begin{array}{l}\text { Mean } \\
\mathrm{N} \\
\text { Std. Dev. } \\
\text { Eta sq } \\
\text { Sig }\end{array}$ & $\begin{array}{c}5,4 \\
92 \\
1,6 \\
.4 \\
, 0\end{array}$ & $\begin{array}{r}5,3 \\
115 \\
1,6 \\
, 4 \\
, 0\end{array}$ & $\begin{array}{r}5,5 \\
116 \\
1,7 \\
, 3 \\
, 0\end{array}$ & $\begin{array}{r}5,7 \\
118 \\
1,8 \\
.4 \\
.0\end{array}$ & $\begin{array}{r}6,3 \\
117 \\
1,7 \\
, 6 \\
, 0\end{array}$ & $\begin{array}{r}6,5 \\
119 \\
1,6 \\
.4 \\
.0\end{array}$ \\
\hline
\end{tabular}

Source: By the author. 
Appendix 9 Human Rights scores: 1972-2001

\begin{tabular}{|c|c|c|c|c|c|}
\hline Group & & DEM 7276 & DEM 8185 & DEM 9195 & DEM 9501 \\
\hline Nafta & $\begin{array}{l}\text { Mean } \\
\mathrm{N} \\
\text { Std. Dev. }\end{array}$ & $\begin{array}{l}8,7 \\
3 \\
2,3\end{array}$ & $\begin{array}{l}8,7 \\
3 \\
2,3\end{array}$ & $\begin{array}{l}8,6 \\
3 \\
2,5\end{array}$ & $\begin{array}{l}8,9 \\
3 \\
2\end{array}$ \\
\hline mercosur & $\begin{array}{l}\text { Mean } \\
\mathrm{N} \\
\text { Std. Dev. }\end{array}$ & $\begin{array}{l}4,7 \\
4 \\
1 \\
\end{array}$ & $\begin{array}{l}5,6 \\
4 \\
1,3 \\
\end{array}$ & $\begin{array}{l}7,6 \\
4 \\
1 \\
\end{array}$ & $\begin{array}{l}7,5 \\
4 \\
1,4 \\
\end{array}$ \\
\hline asean & $\begin{array}{l}\text { Mean } \\
\mathrm{N} \\
\text { Std. Dev. }\end{array}$ & $\begin{array}{l}3,9 \\
8 \\
1,5\end{array}$ & $\begin{array}{l}3,4 \\
9 \\
2,2\end{array}$ & $\begin{array}{l}3,4 \\
9 \\
2,0\end{array}$ & $\begin{array}{l}3,8 \\
9 \\
2,4\end{array}$ \\
\hline eu & $\begin{array}{l}\text { Mean } \\
\mathrm{N} \\
\text { Std. Dev. }\end{array}$ & $\begin{array}{c}8,7 \\
15 \\
2\end{array}$ & $\begin{array}{c}9,6 \\
15 \\
, 5\end{array}$ & $\begin{array}{c}9,7 \\
15 \\
, 4\end{array}$ & $\begin{array}{c}9,6 \\
15 \\
, 5\end{array}$ \\
\hline arab league & $\begin{array}{l}\text { Mean } \\
\mathrm{N} \\
\text { Std. Dev. }\end{array}$ & $\begin{array}{c}2,9 \\
16 \\
1,6 \\
\end{array}$ & $\begin{array}{c}3,1 \\
16 \\
1, \\
\end{array}$ & $\begin{array}{c}2,6 \\
17 \\
1,4 \\
\end{array}$ & $\begin{array}{c}2,6 \\
19 \\
1,3\end{array}$ \\
\hline sadc & $\begin{array}{l}\text { Mean } \\
\mathrm{N} \\
\text { Std. Dev. }\end{array}$ & $\begin{array}{l}4,3 \\
9 \\
2,3\end{array}$ & $\begin{array}{c}3,7 \\
11 \\
2,5\end{array}$ & $\begin{array}{c}5,4 \\
12 \\
2,3\end{array}$ & $\begin{array}{c}5,9 \\
12 \\
2,\end{array}$ \\
\hline ecowas & $\begin{array}{l}\text { Mean } \\
\mathrm{N} \\
\text { Std. Dev. }\end{array}$ & $\begin{array}{c}2,7 \\
12 \\
1,1 \\
\end{array}$ & $\begin{array}{c}3,1 \\
12 \\
1,5 \\
\end{array}$ & $\begin{array}{c}4,2 \\
12 \\
1,8\end{array}$ & $\begin{array}{c}4,9 \\
12 \\
1,8\end{array}$ \\
\hline cacm & $\begin{array}{l}\text { Mean } \\
\mathrm{N} \\
\text { Std. Dev. }\end{array}$ & $\begin{array}{l}6,8 \\
5 \\
2,2\end{array}$ & $\begin{array}{l}5,9 \\
5 \\
2,8\end{array}$ & $\begin{array}{l}6,9 \\
5 \\
1,8\end{array}$ & $\begin{array}{l}7,4 \\
5 \\
1,2\end{array}$ \\
\hline andean & $\begin{array}{l}\text { Mean } \\
\mathrm{N} \\
\text { Std. Dev. }\end{array}$ & $\begin{array}{l}5,4 \\
5 \\
2,8 \\
\end{array}$ & $\begin{array}{l}8 \\
5 \\
, 9\end{array}$ & $\begin{array}{l}6,7 \\
5 \\
1,4 \\
\end{array}$ & $\begin{array}{l}6,7 \\
5 \\
1,1 \\
\end{array}$ \\
\hline cis & $\begin{array}{l}\text { Mean } \\
\mathrm{N} \\
\text { Std. Dev. }\end{array}$ & $\begin{array}{l}2,2 \\
1\end{array}$ & $\begin{array}{l}1,5 \\
1\end{array}$ & $\begin{array}{c}4,3 \\
12 \\
1,7\end{array}$ & $\begin{array}{c}4 \\
12 \\
1,9 \\
\end{array}$ \\
\hline apec & $\begin{array}{l}\text { Mean } \\
\mathrm{N} \\
\text { Std. Dev. }\end{array}$ & $\begin{array}{c}5,6 \\
17 \\
3,1\end{array}$ & $\begin{array}{c}6,1 \\
20 \\
3\end{array}$ & $\begin{array}{l}6,4 \\
20 \\
2,8\end{array}$ & $\begin{array}{l}6,8 \\
20 \\
2,7\end{array}$ \\
\hline nordic & $\begin{array}{l}\text { Mean } \\
\mathrm{N} \\
\text { Std. Dev. }\end{array}$ & $\begin{array}{l}9,7 \\
5 \\
.7 \\
\end{array}$ & $\begin{array}{l}9,7 \\
5 \\
, 7 \\
\end{array}$ & $\begin{array}{r}10 \\
5 \\
.0\end{array}$ & $\begin{array}{r}10 \\
5 \\
.0\end{array}$ \\
\hline $\begin{array}{l}\text { org islamic } \\
\text { conf }\end{array}$ & $\begin{array}{l}\text { Mean } \\
\mathrm{N} \\
\text { Std. Dev. }\end{array}$ & $\begin{array}{c}3,1 \\
38 \\
1,7\end{array}$ & $\begin{array}{c}3,1 \\
39 \\
1,5\end{array}$ & $\begin{array}{c}3,5 \\
46 \\
1,8\end{array}$ & $\begin{array}{c}3,5 \\
48 \\
1,7\end{array}$ \\
\hline Total & $\begin{array}{l}\text { Mean } \\
\mathrm{N} \\
\text { Std. Dev. } \\
\text { Eta sq. } \\
\text { Sig. }\end{array}$ & $\begin{array}{c}4,7 \\
138 \\
2,9 \\
, 6 \\
, 000\end{array}$ & $\begin{array}{c}4,9 \\
145 \\
3,0 \\
, 6 \\
, 000\end{array}$ & $\begin{array}{c}5,1 \\
165 \\
2,9 \\
, 6 \\
, 000\end{array}$ & $\begin{array}{c}5,2 \\
169 \\
2,9 \\
, 6 \\
, 000\end{array}$ \\
\hline
\end{tabular}

Source: By the author. 


\section{Appendix 10 Variable list}

\begin{tabular}{|l|l|l|}
\hline Abbreviation & $\begin{array}{l}\text { Description } \\
\text { The democracy scores are based on the Freedom House } \\
\text { scores where a low degree of democracy scores 1 and } \\
\text { a high degree of democracy scores 10 }\end{array}$ & $\begin{array}{l}\text { Fources } \\
\text { FREDOM HouSE } \\
2002\end{array}$ \\
\hline CORR & $\begin{array}{l}\text { Perceived corruption scores transformed so that higher } \\
\text { scores stands for more of perceived corruption, and lower } \\
\text { scores stands for less of perceived corruption }\end{array}$ & $\begin{array}{l}\text { TRANSPARENCY } \\
\text { INTERNATIONAL } \\
\text { 2003 }\end{array}$ \\
\hline ECFR & $\begin{array}{l}\text { Index of economic freedom as estimated by the Fraser } \\
\text { Institute and where high scores indicate a high degree of } \\
\text { economic freedom and low scores indicate a low degree } \\
\text { of economic freedom }\end{array}$ & $\begin{array}{l}\text { GWARTNEY and } \\
\text { LAWSON 2001 }\end{array}$ \\
\hline GDPCPP & $\begin{array}{l}\text { Gross domestic product per capita expressed as } \\
\text { purchase power parities in US \$ }\end{array}$ & WORLD BANK 2000 \\
\hline GRO & Annual per capita economic growth & WORLD BANK 2000 \\
\hline HDI & Human Development Index & UNDP 2001 \\
\hline IMPEX & Imports and exports in percentage of GDP & WORLD BANK 2000 \\
\hline INFL & Average inflation rates for various periods of time & WORLD BANK 2000 \\
\hline
\end{tabular}

Source: By the author. 


\section{References}

Balassa, Bela A. (1961), The Theory of Economic Integration. Homewood: R.D. Irwin 1961; London: Allen \& Unwin 1973; Westport: Greenwood Press, 1982.

CIA (2001), The World Factbook 2001. London: Brassey's.

Clement, Norris C. (et al.) (2000), North American Economic Integration: Theory and Practice. Aldershot: Edward Elgar.

Freedom House (2002), Annual Survey of Freedom Country Scores 1972-73 to 2000-01, Internet: http://www.freedomhouse.org/ratings (as of 24 July 2006).

GWARTNEy, JAMES and Robert LaWSON (2001), Economic Freedom of the World 2001 Annual Report. Vancouver, BC: the Fraser Institute, Internet: http://www.freetheworld.com/release.html (as of 24 July 2006).

Krugman, Paul R. and Maurice Obsfeld (2002), International Economics: Theory and Policy. New York: Addison-Wesley.

Molle, Willem (2001), The Economics of European Integration: Theory, Practice, Policy, $4^{\text {th }}$ edition, Burlington: Ashgate.

Tovias, Alfred (1991), A Survey of the Theory of Economic Integration, Journal of European Integration 15 (1), pp. 5-23.

Transparency International (2003), Corruptions Perceptions Index, Internet: http://www.transparency.org/cpi/index.html\#cpi (as of 24 July 2006).

UNDP (2001), Human Development Report. New York: Oxford University Press.

Veblen, Thorstein (1994), The Theory of the Leisure Class. New York: Dover.

Weber, Max (1978), Economy and Society. Berkeley: University of California Press.

WORLD BANK (2000), World Development Indicators 2000. Washington, DC: World Bank (on CD-ROM). 